\title{
Historical Ecology in Kiribati: Linking Past with Present ${ }^{1}$
}

\author{
Frank R. Thomas ${ }^{2}$
}

\begin{abstract}
Compared with "high" islands, atolls and table reefs have received litthe attention from archaeologists focusing on historical ecology in Oceania. Limited archaeological investigations in the three archipelagoes composing the Republic of Kiribati (Gilbert, Phoenix, and Line Groups) reflect primarily culture historical reconstructions. Given the unique environmental challenges posed by coral islands, their potential for prehistoric ecological research should be recognized. By contrast, the last 50 years have witnessed a host of environmental studies, from agricultural improvements to sea-level rise and contemporary human impact on terrestrial and marine resources. In an attempt to better understand the influence of natural and human-induced processes in the more distant past, this paper explores several themes of relevance to coral islands in general. These include (1) natural and anthropogenic change on geomorphology and ecosystems, (2) anthropogenic impacts on faunal resources, (3) environmental evidence for human colonization, (4) interisland exchange networks and population mobility, and (5) social evolution.
\end{abstract}

As ISLANDS FORMED by biogenic agents (unconsolidated carbonate sediments deposited by waves on reef platforms), atolls and table reefs, or low coral islands without lagoons, can be regarded as especially constraining habitats for human communities (BaylissSmith 1977, Brady 1978, Liew 1990). The challenges faced by human populations, both past and present, include low soil fertility, absence of perennial surface freshwater, and extreme vulnerability to flooding by storm surge due to low elevation of the highly fragmented landmass, only a few meters above mean sea level. There are some 300 atolls and low coral islands in Oceania and many more individual islets. Several archipelagoes are dominated by these kinds of limestone islands, such as the Tuamotus, the Marshall Islands, Tuvalu, and Kiribati (Figure 1).

\footnotetext{
${ }^{1}$ Manuscript accepted 30 November 2008.

2 Pacific Studies, Oceania Centre for Arts, Culture and Pacific Studies, University of the South Pacific, Suva, Fiji (e-mail: thomas_fr@usp.ac.fj).
}

Pacific Science (2009), vol. 63, no. 4:567-600

(C) 2009 by University of Hawai'i Press

All rights reserved
Although coral islands have been the focus of detailed ethnographic research beginning in the early decades of the twentieth century (e.g., Buck 1932a,b, Beaglehole and Beaglehole 1938, Krämer and Nevermann 1938), archaeological coverage was mainly concerned in documenting surface remains (Emory 1934a,b, 1939). It was assumed that because of their marginal environment, such islands must have been settled relatively late, after the better endowed high islands had been colonized. In view of their geomorphologic instability, it was also believed that catastrophic disturbances would have obliterated most traces of subsurface cultural deposits.

It was not until the mid-1960s, through the efforts of Janet Davidson $(1967,1971)$ in her pioneering excavations on the Polynesian outlier of Nukuoro, that the presence of in situ cultural layers was confirmed. The 1970s and 1980s witnessed an expansion in coral island research, with partial coverage of the Caroline and Marshall islands (Sinoto 1984, Dye 1987b). The Caroline Islands data further demonstrated that stratified deposits, albeit disturbed, could still be identified even on atolls and other island types located in the cyclone belt (Intoh 2008). As was characteristic of most of the archaeology in Oceania at the time, questions of origin through the 


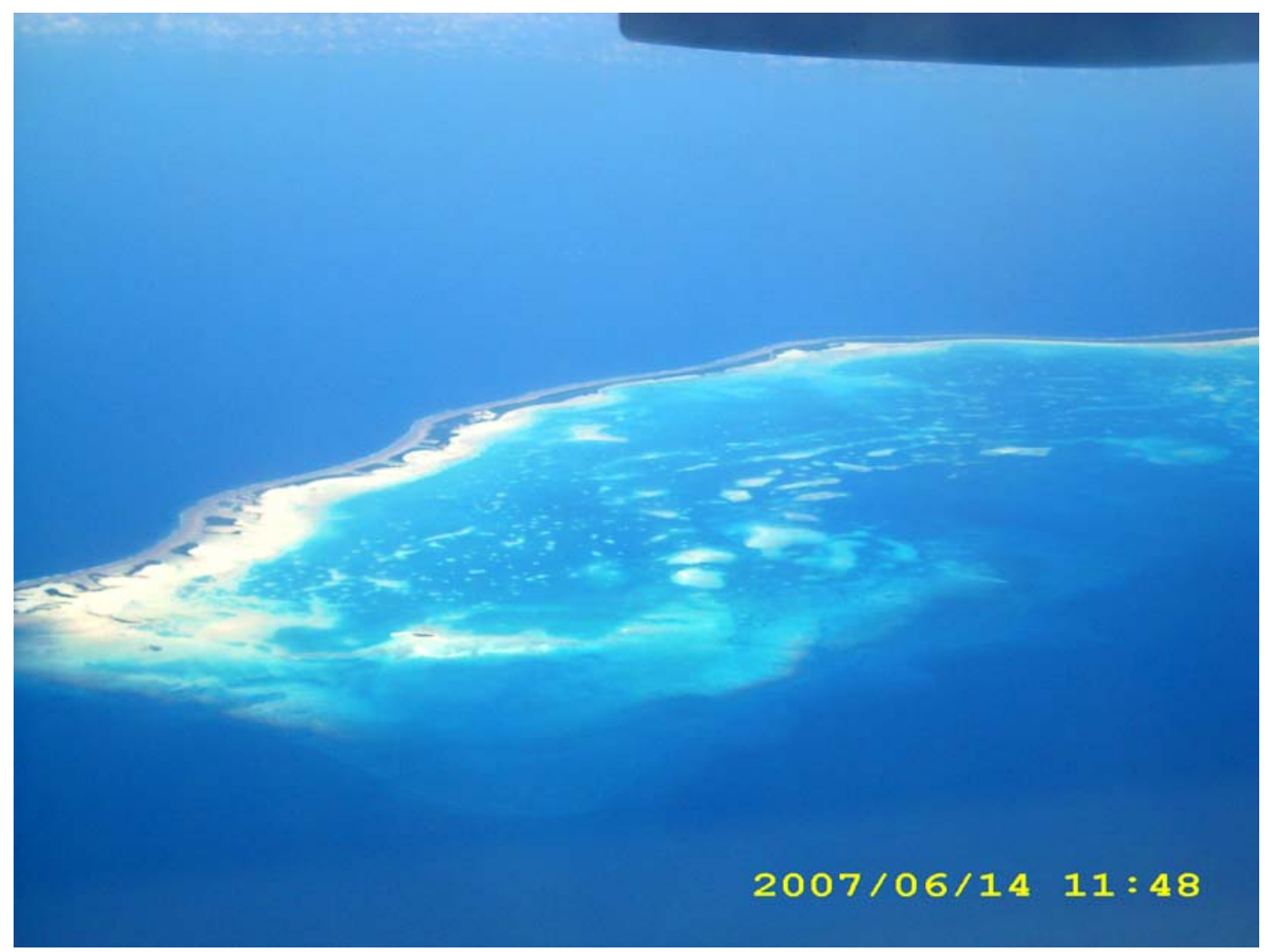

Figure 1. One of the Gilbert atolls from the air.

study of artifact types dominated the research agenda.

Kiribati offers great potential for further archaeological research, given the environmental variability found among its atolls and table reefs scattered over vast ocean distances. There is a need to gather more information on local chronologies and to increase our understanding of past human ecology.

I explore themes in historical ecology initially proposed by Kirch and Hunt (1997) on several "high" islands in Oceania, as they might apply to coral island research. Data collected by Alkire (1978) on coral island societies using an ecological framework are also presented and further discussed in the Kiribati context. Much of what follows is speculative given the paucity of data in support of hypotheses and scenarios over alternative views. By attempting to synthesize existing bodies of information, however, we can provide some directions for future research. Given the unique environmental challenges confronting human communities on coral islands, their potential for prehistoric ecological research should be recognized. Topics of interest to historical ecologists include natural and anthropogenic change on geomorphology and ecosystems, anthropogenic impacts on faunal resources, environmental evidence for human colonization, interisland exchange networks and population mobility, and social evolution.

\section{PHYSICAL SETTING}

\section{Geography and Geology}

The Republic of Kiribati consists of 33 atolls and table reefs spread over an area exceeding 
3 million $\mathrm{km}^{2}$ of ocean straddling the equator between $04^{\circ} 43^{\prime} \mathrm{N}$ and $11^{\circ} 25^{\prime} \mathrm{S}$ latitude and between $169^{\circ} 32^{\prime} \mathrm{E}$ and $150^{\circ} 14^{\prime} \mathrm{W}$ longitude. The total land area, however, only slightly exceeds $800 \mathrm{~km}^{2}$ (Figure 2).

The Gilbert Islands, also referred to as western Kiribati, are a group of 16 atolls and reef islands. Banaba (Ocean Island), which lies some $400 \mathrm{~km}$ west of the main group and attains an elevation of $80 \mathrm{~m}$, is sometimes considered to be part of the archipelago as a result of intensive social and political interaction with the Gilberts in recent history.

The Gilbert Islands are spread over 640 $\mathrm{km}$ on both sides of the equator at the southeastern edge of Micronesia between $03^{\circ} 30^{\prime}$ $\mathrm{N}$ and $02^{\circ} 45^{\prime \prime} \mathrm{S}$ latitude and between $172^{\circ}$ $30^{\prime} \mathrm{E}$ and $177^{\circ} 00^{\prime} \mathrm{E}$ longitude. The total land area for the group is about $280 \mathrm{~km}^{2}$. Excluding Banaba, three subgroups within the Gilberts can be distinguished on the basis of rainfall: north (Makin and Butaritari), central (from Marakei to Aranuka), and south (from Nonouti to Arorae) (Catala 1957). Tarawa is the seat of government and main commercial center, with the southern part of the atoll consisting of mixed rural and urbanized sections.

About 1,400 km east of the Gilberts lies the Phoenix Group, a cluster of eight largely uninhabited atolls and reef islands. Farther east are the Line Islands, including Kiritimati (Christmas Island) located some $3,330 \mathrm{~km}$ from Tarawa and 2,100 km southeast of Honolulu. Kiritimati is the world's largest atoll in terms of landmass $\left(388 \mathrm{~km}^{2}\right)$, accounting for almost half of Kiribati's dry surface but only about $4 \%$ of the population, which is concentrated in the Gilbert Group and especially on South Tarawa.

\section{Climate}

Most of the Gilbert Islands and several of the Line and Phoenix islands are located in the dry belt of the equatorial oceanic climatic zone. Islands located within $5^{\circ}$ of the equator normally experience two wet seasons because the Intertropical Convergence Zone (ITCZ) crosses the region twice a year (Sturman and McGowan 1999). However, rainfall is extremely variable, both annually and between islands, being strongly influenced by the $\mathrm{El}$ Niño-Southern Oscillation (ENSO) (Burgess 1987). Precipitation ranges from about $3,000 \mathrm{~mm}$ in the north (Butaritari) to 1,100 $\mathrm{mm}$ in the south (Tamana) in the Gilbert Group and from about 4,000 $\mathrm{mm}$ (Teraina) in the Line Islands to less than $800 \mathrm{~mm}$ on Kanton (Phoenix Group) (Hoare 19961998). Prolonged drought conditions are common, notably in the central and southern Gilberts, many of the Phoenix Islands, and Kiritimati. Cyclones are rare. Temperatures show little seasonal differences. Daytime maxima are high, averaging between $31^{\circ} \mathrm{C}$ and $33^{\circ} \mathrm{C}$, although humidity is more variable among the islands.

\section{Soils and Hydrology}

The highly alkaline and coarse-textured coral-derived soils of Kiribati are among the poorest in the world. They are typically shallow with very little water-holding capacity, little organic matter, and low available macro- and micronutrients apart from calcium, sodium, and magnesium (Thaman 1992). Because soils are alkaline, fertility is dependent on organic matter for the concentration and recycling of plant nutrients and for soil water retention in excessively welldrained soils. Organic carbon values for subsoils are low $(<0.5 \%)$ unless there has been considerable disturbance such as that associated with the digging of babai, or swamp taro (Cyrtosperma chamissonis), pits (Figure 3). Phosphate soils, which were once extensive on Banaba before large-scale mining beginning in the early twentieth century, are found in scattered locations throughout Kiribati.

Owing to their small size, low elevation, and the porosity of the coral bedrock, there are no surface streams on the atoll islands. Instead rainfall soaks through the porous surface soil creating the Ghyben-Herzberg lens of often slightly brackish water floating on top of higher-density saltwater. Apart from small amounts of water that may be collected from coconut palm fronds and trunks during precipitation, as well as from discarded giant clam shells, the lens is the only source of potable water. More recently, concrete cisterns, empty oil drums, and plastic storage tanks 


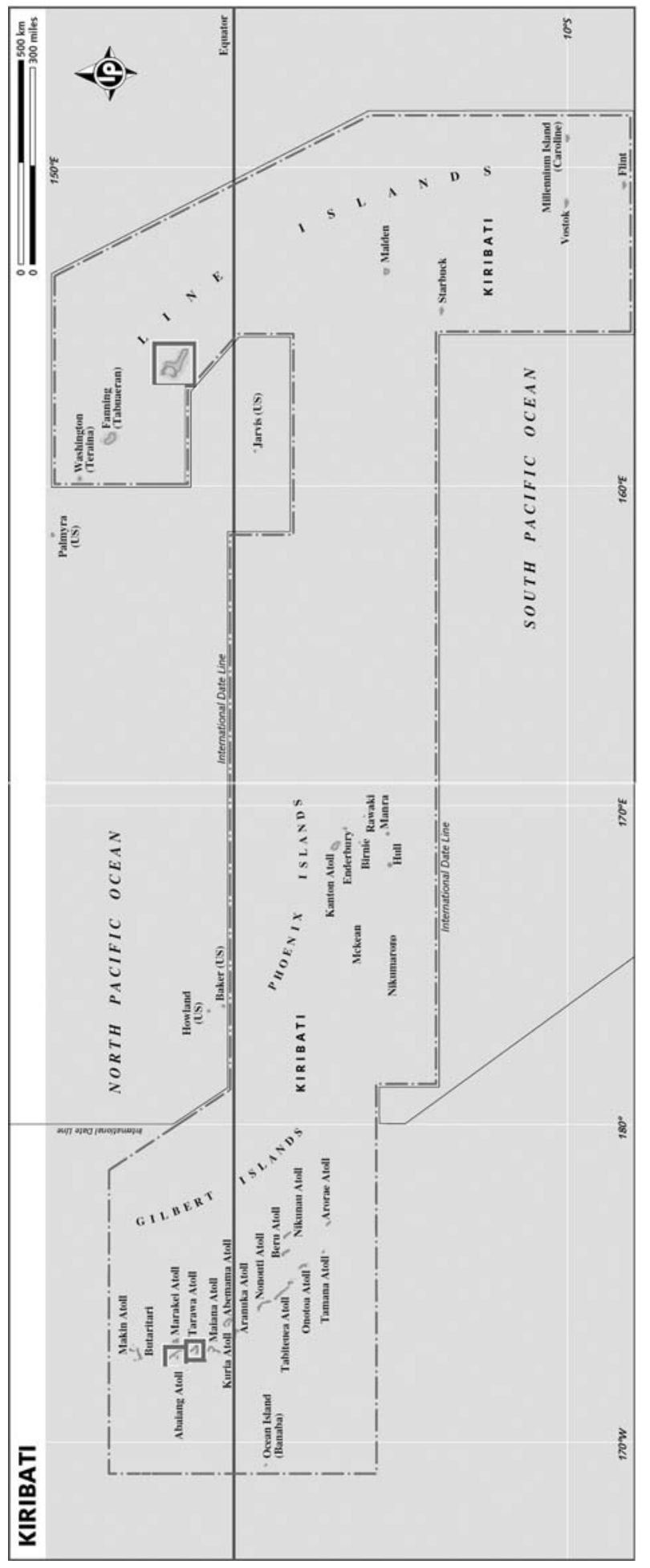

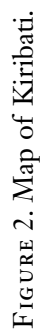




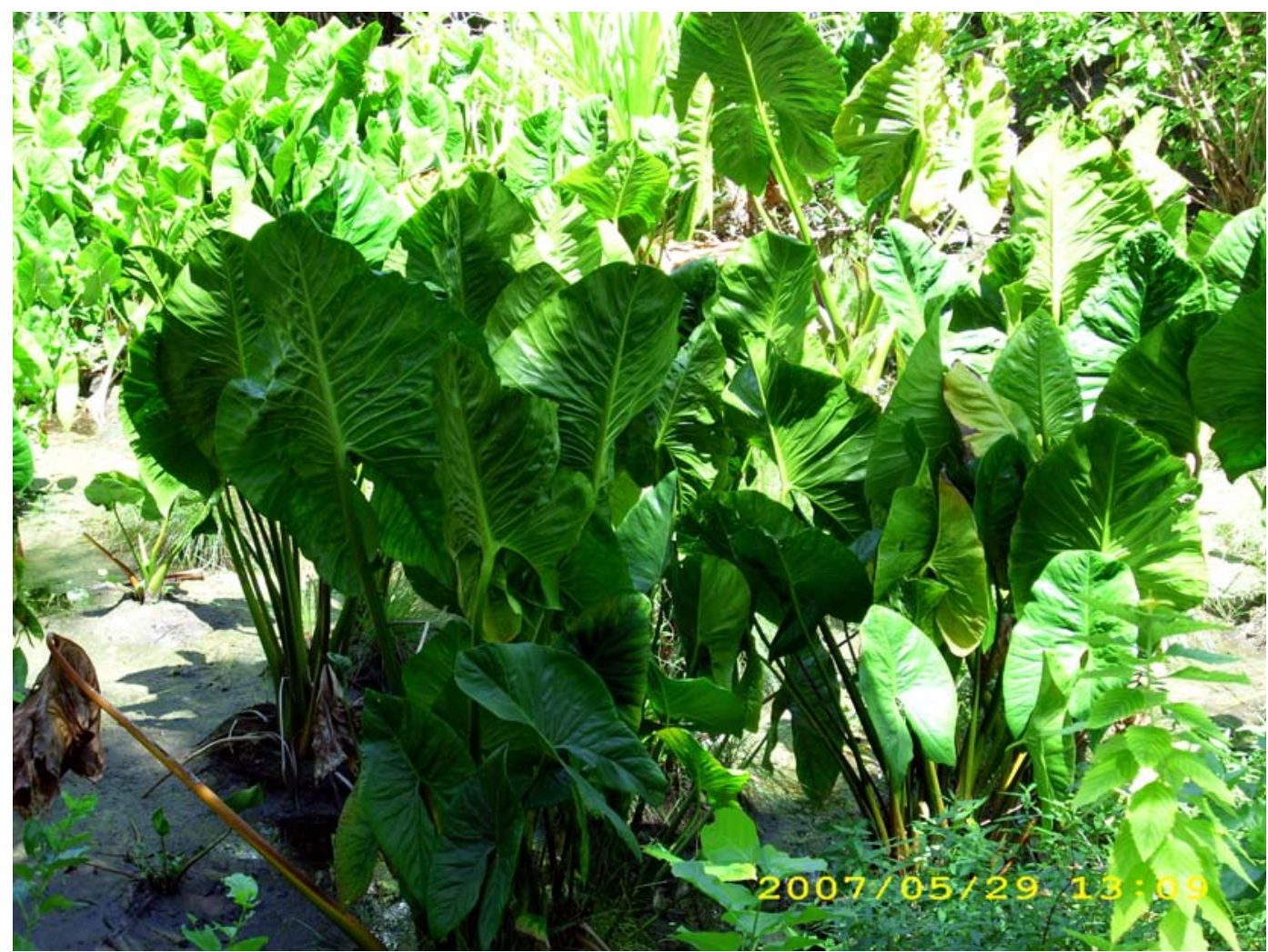

Figure 3. Swamp taro (Cyrtosperma chamissonis) in pit.

have provided alternative means to collect rainwater. Generally, salinity decreases from both lagoon and ocean beaches toward the center of islets. The location and degree of groundwater development influences the surrounding vegetation, as well as the location of village wells and cultivation pits. Unchecked urbanization and population growth on South Tarawa have resulted in sewage seeping into the groundwater at several locations.

Of concern for the future of human habitability, including access to drinking water and agricultural production, is the threat of global warming and associated rise in sea level (Nunn 2001).

\section{ARCHAEOLOGICAL COVERAGE}

The three island groups that compose Kiribati have received uneven coverage of their tangible cultural resources, and only a few excavations have been undertaken. Unlike the atolls in the jurisdictions that were once part of the former U.S. Trust Territory of the Pacific Islands ("American Micronesia"), and that have benefited from the historic preservation program of the U.S. National Park Service, Kiribati lacks a comprehensive heritage-management agenda. This is largely attributable to limited financial resources.

Excavations on the raised (makatea) coral island of Banaba were carried out in the mid-1960s (Lampert 1968, Sigrah and King 2001), yielding dates not older than 300 to 400 years ago. Owing to the heavy exploitation of phosphate deposits throughout the twentieth century, much surface cover has been removed, likely destroying a substantial part of the archaeological record.

Within the Gilbert Group, the first ar- 
chaeological excavation was initiated in 1983 on the small reef island of Makin (Takayama and Takasugi 1987, 1988, Takayama 1988). This was followed by excavations on North Tarawa and the southern reef island of Tamana (Takayama et al. 1989, 1990). Much of that work, as elsewhere in Kiribati, focused on culture history and the typological approach. Radiocarbon dating on Nikunau (southern Gilberts) suggests initial occupation about 2,000 years ago, consistent with the earliest dates for the neighboring Marshall Islands to the north (Riley 1987, Shun and Athens 1990, Di Piazza 1999, Weisler $1999 a, b, 2000,2001 b$ ). It should be noted that there are controversial dates from Bikini Atoll in the northern Marshalls, the site of nuclear testing during the 1940s and 1950s, that suggest settlement occurred contemporaneously with the Lapita expansion into the Southwest Pacific before 800 B.C. (Streck 1990). Because contamination of carbon samples by modern radioactivity would produce younger, not older dates (Rainbird 2004:86), results could be derived from old drift logs of long-lived species, such as those found along the west coast of North America (Kirch and Weisler 1994).

Archaeology in the Phoenix and Line islands goes back to the 1920s and 1930s with work conducted by Kenneth Emory and Gordon Macgregor of the Bishop Museum (Emory 1934b, Macgregor n.d.). Later surveys and excavations, including intensive research toward locating Amelia Earhart's crash site on Nikumaroro (Gardner Island), yielded evidence for human settlement dating to the twelfth century A.D. (Sinoto 1973, Throssel and Specht 1989, Anderson et al. 2000, Pearthree and Di Piazza 2003, Di Piazza and Pearthree 2004). In a review of the Phoenix Islands, Carson (1998) concluded that the stone platform structures were reminiscent of eastern Polynesia from the period A.D. 950 to 1500 . Yet, the cultural affiliations of current-day I-Kiribati (Gilbertese), whose ancestors originally settled the Gilbert Group (and the rest of eastern Micronesia), appear to be with groups in the southeastern Solomons and northern Vanuatu on the basis of linguistic and archaeological evidence (Irwin
1992:121-122, Pawley and Ross 1993, Rainbird 2004:233). However, links between the Gilberts and Polynesian areas are manifest in architecture and words, particularly in the adoption of West Polynesian nautical terminology (Marck 1986, Geraghty 1994, Rainbird 2004:232). The Gilberts and Kosrae are both probable locations for the Proto Nuclear Micronesian homeland (Lynch et al. 2002:117-118). When the first Europeans landed in the Line and Phoenix groups, all of these islands were uninhabited yet showed signs of earlier sustained occupation, prompting the label "mystery islands" to describe them together with other similar localities such as Pitcairn Island of Bounty fame, Henderson, Norfolk, and Nīhoa and Necker in the Hawaiian Chain (Bellwood 1979:352).

\section{PREVIOUS ECOLOGICAL RESEARCH}

Fifty years ago R. L. A. Catala published his seminal work on the human ecology of the Gilbert Islands (Catala 1957). A number of reports have subsequently appeared in the Atoll Research Bulletin and other publications mainly focusing on physical geography and natural history of the three archipelagoes but also including important human/environment studies such as Thaman's (1990) description of agroforestry and several reports on the state of marine resources (Beets 2001, Johannes and Yeeting 2001, Paulay 2001, Tebano and Paulay 2001, Thomas 2001a, 2003a). The Tarawa Lagoon Project, a major interdisciplinary environmental assessment survey (Abbott and Garcia 1995), has greatly contributed to our understanding of recent human impact on marine ecosystems on the main atoll. There are also case studies on social change with close ties to environmental issues affecting individual communities (Lundsgaarde 1966, Geddes et al. 1982, Geddes 1983, Lawrence 1983, Sewell 1983, Watters and Banibati 1984) and broad socioeconomic analyses (Van Trease 1993, Thomas and Tonganibeia 2007). All of these analyses suggest that on such small, resourcepoor islands human ecological linkages are more clearly visible than in most other settings (cf. Alkire 1965, 1978). 
Although still regarded by some observers as one of the most traditional areas of Micronesia, Kiribati has witnessed accelerated environmental and social changes in the decades following independence from Great Britain in 1979 (World Bank 2000, Thomas 2003b). These changes might have gone unnoticed by the rest of the world were it not for media attention on the effects of rising sea levels attributable to global warming and the publicity surrounding the millennium celebrations on remote Caroline Island in the southern Line Group, renamed Millennium Island for the occasion.

Since 1993, I have conducted a series of ecological projects primarily focusing on contemporary marine resources exploitation but also covering traditional tenure systems and agricultural production (Thomas 2001b, $2002 b, 2003 c, d)$. Attempts to understand human/environment relations on some of the Gilbert atolls in the more distant past used ethnoarchaeological data combined with approaches from human behavioral ecology, and direct assessment of indigenous archaeological sites (Thomas 2002a, 2007a,b, Thomas and Teaero 2009).

\section{DIRECTIONS IN HISTORICAL ECOLOGY RESEARCH ON CORAL ISLANDS}

Compared with "high" islands, atolls and table reefs have received scant attention from archaeologists focusing on historical ecology (Kirch and Hunt 1997, McNeill 2001, Garden 2005, Fitzpatrick and Keegan 2007). More specifically, little is known about cultural development and change and the extent of human-induced environmental impacts among Micronesian atolls before Western contact (Weisler 2001b, Anderson 2002). Major environmental disturbance during the first half of the twentieth century and in the years just before independence includes the aforementioned destruction of the landscape on Banaba for extracting phosphate (Macdonald 2001); the effects of World War II bombings, particularly on Betio Islet, South Tarawa (Figure 4) (McQuarrie 2000); and nuclear tests off Malden (southern Line Islands) and Kiritimati between 1957 and 1962 (Perry and Garnett 1998). Although the nuclear tests are said to have brought no lasting contamination on land, the veil of secrecy has only recently lifted around similar tests in the Marshall Islands between 1946 and 1958, and there are reported instances of illness among British and Pacific Islander servicemen who witnessed these tests and their descendants. It remains to be proven that the environment (marine and terrestrial) on both Malden and Kiritimati is safe for long-term human habitation. Owing to population pressure, agrodeforestation continues with the widespread removal of coastal strand species and mangroves for fuelwood and other uses (Thaman 1990).

What is needed is a better understanding of the processes in historical ecology (cf. Crumley 1994, Kirch and Hunt 1997, Balée 1998, Scoones 1999) that took place on coral islands, such as Kiribati, from the first documented arrival of human settlers some 2,000 years ago to European contact, and how natural and anthropogenic influences have shaped the sociocultural trajectories of various communities. We know that some groups were able to live sustainably for generations, but others became extinct, as the evidence for the Phoenix and Line islands bears testimony. What were the keys to human survival on one hand, and what led to the demise of different groups on the other? An understanding of survival, sustainable lifeways, and population demise on atolls may have something to teach modern populations in the $\mathrm{Pa}$ cific and elsewhere.

\section{Natural and Anthropogenic Change on Geomorphology and Ecosystems}

Since the 1970s, archaeologists working in the Pacific, with support from environmental scientists, have contributed a great deal toward our understanding of the processes of landscape change coinciding with the arrival of early settlers and continuing throughout the prehistoric sequence on islands under investigation, with implications for demographic change, agricultural intensification, and the development of social complexity (Kirch 1984, Kirch and Hunt 1997, Leach 


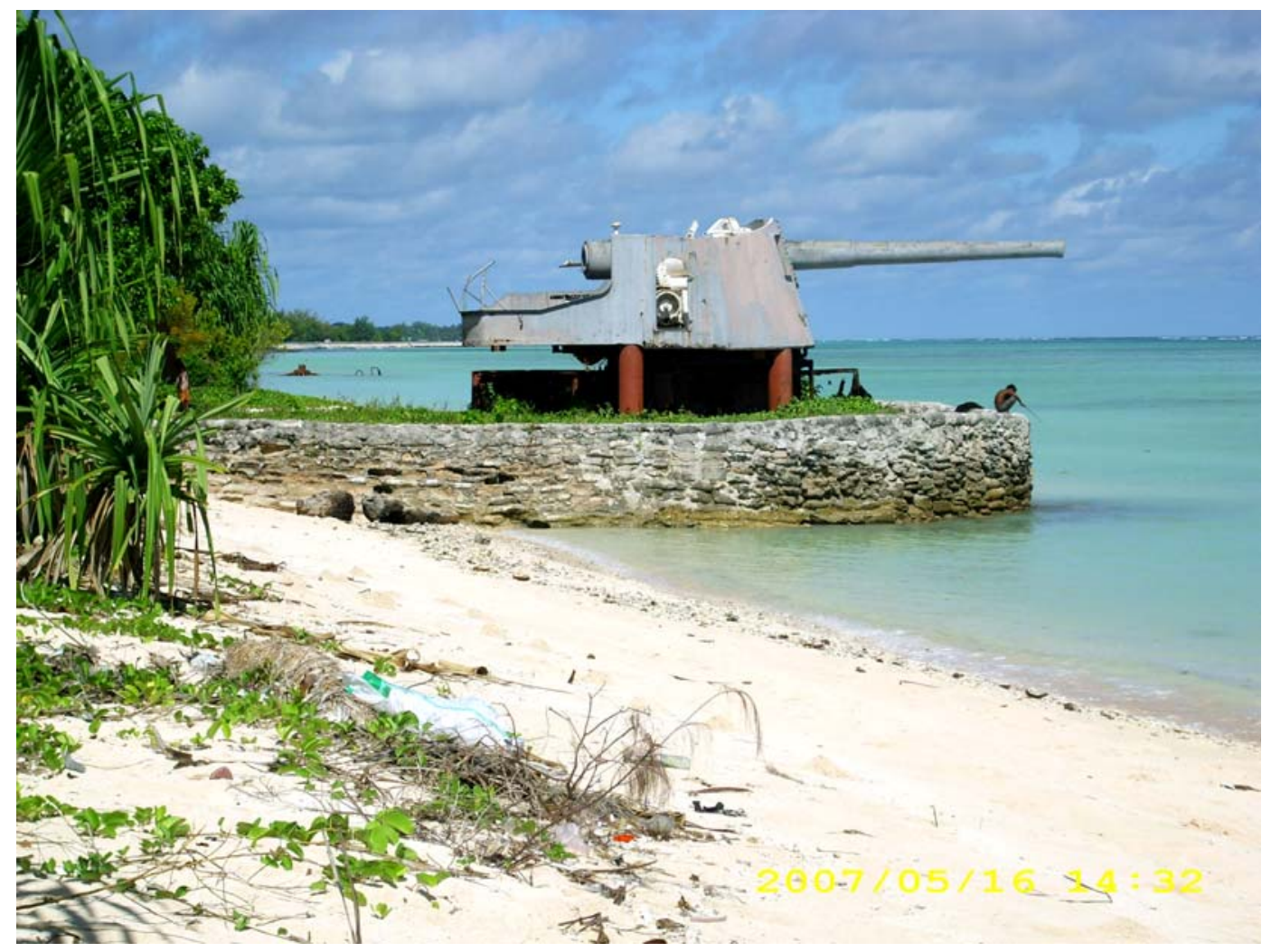

Figure 4. One of the Japanese 8 -inch $(20 \mathrm{~cm})$ guns at Betio, Tarawa.

1999, Thomas 1999, Kirch and Rallu 2007). It can no longer be assumed that indigenous populations, unlike later cultural groups, had exerted only minimal influence on their physical surroundings. The scale of environmental disturbance has accelerated with European intrusion, but it is clear that many indigenous societies impacted both terrestrial and marine environments, sometimes in substantial ways. Besides measuring the degree of environmental change, historical ecologists are also challenged in their attempts to disentangle the effects of natural processes from those induced by humans (Kirch 1997b, Fitzpatrick and Donaldson 2007, Nunn et al. 2007).

Low coral islands are quite recent on a geological timescale, having formed on top of extinct volcanoes that have slowly sub- sided, allowing for reef buildup. The oceanic crust in the Gilbert Group is dated to 139 million years ago and 128 million years in the Line Group (Jackson and Schlanger 1976, Gillie 1993). With the exception of seismic activity reported in the early 1980s near the southern Gilberts (Lay and Okal 1983), Kiribati is considered tectonically stable. However, climatic shifts and change affecting islet morphology have certainly taken place before and after human settlement.

Atoll islets, or motus, constitute the land area above the level of ordinary high tides and typically form a ring with a central lagoon open to the sea via passes. An atoll's long axis is generally perpendicular or oblique to the prevailing winds. Consequently, islet development is more pronounced along the windward margins, whereas deep passes are 


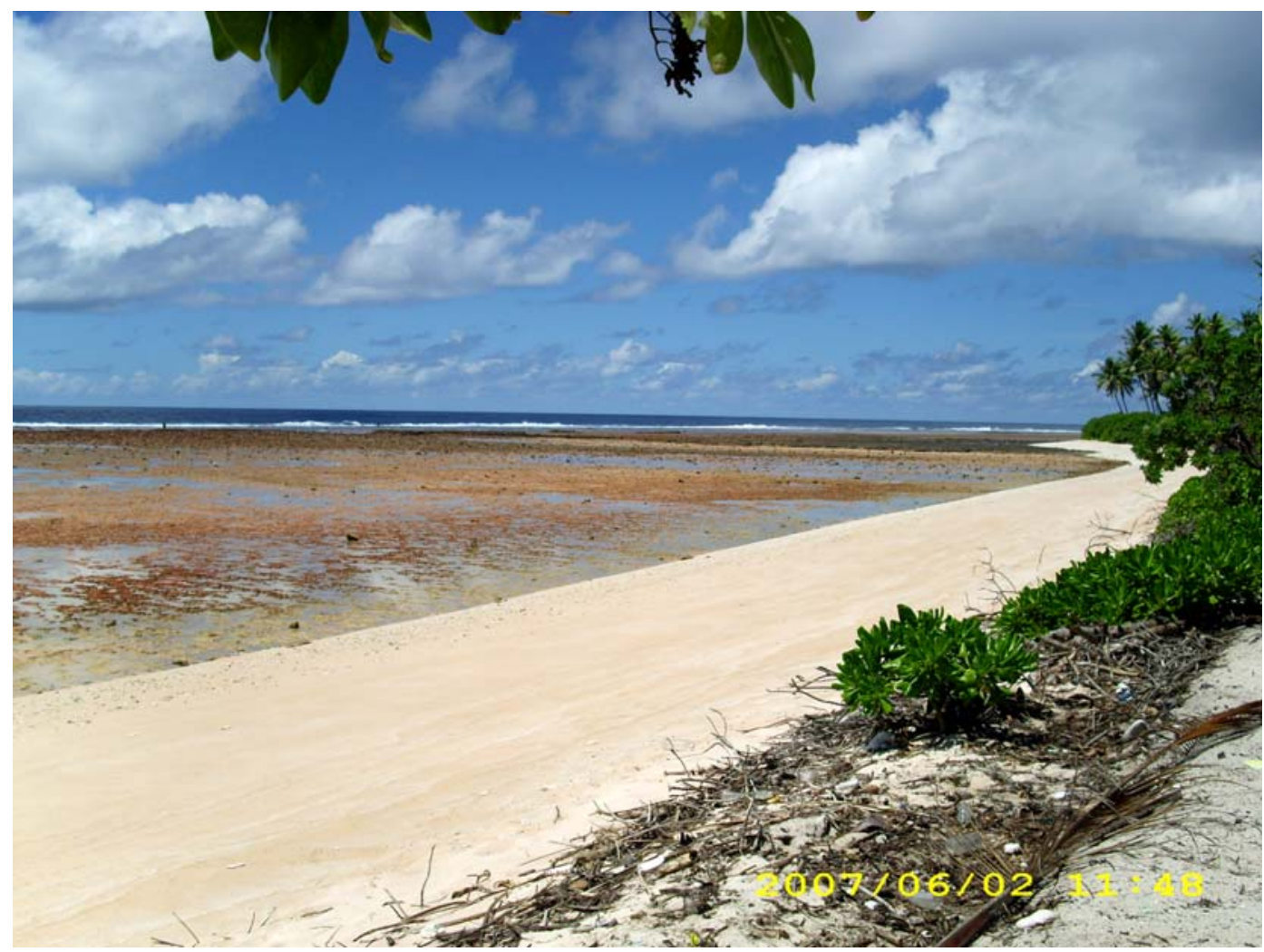

Figure 5. Partial view of an islet along the windward (ocean) side, Abaiang Atoll.

restricted to leeward margins (Figure 5). Islets may differ in size, morphology, and in the variety of plants that they support, but all are susceptible to being flooded by storm waves (Wiens 1962). Of interest to archaeologists is the timing for the development of stable landforms and how local chronologies tie in with the history of human settlement in Remote Oceania.

Once seen as competing with Darwin's subsidence theory, Daly's (Kühlman 1982, Nunn 2001) glacial control hypothesis, which emphasizes the effects of falling and rising sea levels on reef building, has found equal support in explaining the origin and development of atolls. Changes in sea level took place during and after initial settlement of Remote Oceania, but their effects and timing were not uniform throughout the region. Dickin- son (2003) provided an overview of the patterns of human settlement and the geological evidence concerning the emergence above sea level of habitable and/or stepping-stone islands.

Between 35,000 and 30,000 years ago, sea level was near current level but then dropped to some $130 \mathrm{~m}$ below current-day mean at the peak of the last glacial period about 17,000 years ago (Menard 1986:79, Nunn 1999). At that time, former atolls were exposed like makatea islands, similar to current-day $\mathrm{Ba}-$ naba and Nauru. Although Near Oceania supported human populations during those periods, there is no evidence that they had reached Remote Oceania.

Beginning about 13,000 years ago, global sea level began to rise rapidly (Martinson et al. 1987). Drill cores from Tarawa revealed 
leached limestone dating to some 125,000 years ago, overlain by lithologies dating to less than 8,000 years ago (Marshall and Jacobson 1985). Thus, Holocene reef growth is believed to have started around 8,000 years ago.

Data for mid- to late-Holocene higher sea-level stands have been presented for a number of Pacific localities (Grossman et al. 1998, Nunn 1998:243, Dickinson 2003). On Tarawa, a mid-Holocene position of sea level $0.7-0.8 \mathrm{~m}$ above current mean is indicated (Falkland and Woodroffe 1997). Together with evidence from neighboring atolls, reef island formation would not have begun before about 3,500 years B.P. (Schofield 1977, Falkland and Woodroffe 1997). The transition from corals to unconsolidated sediments needed for island buildup varied across time and space, even within the confines of individual atolls (Marshall and Jacobson 1985, Woodroffe and Morrison 2001), and the emergence of land suitable for permanent human occupation appears to have taken place several centuries later.

In his review of mid-Holocene highstand conditions and their relationship with the timing of human settlement, Dickinson (2003) computed a chronology for the decline of sea levels and the crossover dates in different parts of the Pacific island region, finding a close correspondence between the availability of suitable landmass and the appearance of human activities. These crossover dates specify the inferred time for each island group when declining late-Holocene sea level first carried ambient high-tide level below midHolocene low-tide level. Before the crossover date, relict mid-Holocene paleoreef flats were still overtopped by seawater at high tide. The end of highstand for Tuvalu, Kiribati (Gilbert Group), and the Marshall Islands is 200 B.C., with a crossover date of A.D. 1100. By contrast, for the Tuamotus in the eastern Pacific, the highstand ends at A.D. 800, with a crossover date of A.D. 1400. These dates may be used as a baseline when people could have settled low-lying islands.

The Gilberts, together with the Marshalls, have produced some of the earliest dates for human colonization of the central Pacific.
There is now a growing corpus of radiocarbon ages for early cultural horizons on five different atolls and one table reef that fall within the interval A.D. 100-400 (Riley 1987, Shun and Athens 1990, Di Piazza 1999, Weisler 1999a,b, 2000, 2001b). Galipaud (2001) reported on occupation of Ant Atoll, close to Pohnpei, around 2,000 years ago, consistent with the earliest dates from the Gilberts and the Marshalls, as well as the high islands of the eastern Carolines. Additional early dates are expected from other atolls in the eastern Carolines and Tuvalu, although the sparse evidence for the latter so far indicates settlement about A.D. 1000 (Dickinson et al. 1990). Farther east, but still part of Dickinson's (2003) central Pacific cluster, there is evidence for exposed coastal sediments from Kiritimati by about 1000 B.C. (Woodroffe and McClean 1998), prompting Anderson et al. (2000) to suggest that this large atoll could have been settled during the Lapita expansion or later. However, the earliest evidence for human occupation on this and other atolls and table reefs in the Line and Phoenix islands only extends back to the twelfth century A.D. (Pearthree and Di Piazza 2003, Di Piazza and Pearthree 2004).

Based on this evidence, Dickinson (2003) concluded that while mid-Holocene paleoreefs were still intertidal, habitable islets had begun to grow on atoll reefs. The apparent absence of comparable settlement in atoll groups of the South Pacific during that time may relate to the greater tidal range in the central Pacific, allowing relict mid-Holocene paleoreef flats to project farther above lowtide level, enabling accumulation of unconsolidated sediment to form islets at an earlier stage of sea-level decline (cf. Chazine 1984, Montaggioni and Pirazzoli 1984, Pirazzoli and Montaggioni 1986, Chikamori 1996). Thus, the absence of intervening stable landforms on the reefs that would later develop into the atolls of Tokelau and the northern Cooks would have effectively increased relative isolation between the high islands of West and East Polynesia, providing a possible explanation for the chronological gap between Lapita in Samoa and the dates obtained 
from East Polynesia and the intervening atolls (Best 1988, Di Piazza 2005, but see Chikamori and Yoshida 1988).

Dickinson (2003) argued that even on islands exposing volcanic bedrock or uplifted limestone coastal flats most suitable for habitation were largely submerged during highstand conditions. Alternative hypotheses for the centuries-long pause in West Polynesia before the colonization of East Polynesia are presented by Kennett et al. (2006) and Anderson et al. (2006), who suggested that this chronological gap might relate to population infilling and the intensification of subsistence strategies, and increasing difficulty of sailing against the prevailing southeast trades until El Niño events became more frequent and of greater intensity.

Once Pacific atolls became suitable for human habitation, colonists continued to face numerous challenges, particularly in setting up a viable subsistence base given low soil fertility and in some instances erratic rainfall patterns. The range of food crops that could sustain people on low coral islands was limited compared with what could be grown on the more-fertile volcanic islands. Nevertheless, coral island societies devised subsistence strategies that took full advantage of edible wild resources, including abundant marine life, in addition to crops that were successfully introduced.

The most outstanding features of Kiribati and other atoll landscapes, particularly in wetter parts of the tropical Pacific, are the swamp taro pits. Taro pit cultivation has witnessed a general decline on many atolls today. The reasons are varied and include damage by pigs, crop disease, cyclones, growing dependence on food imports, and increasing salinization of the water table associated with global warming and sea-level rise (Thomas 2003b). Ironically, some Pacific Island societies in the past took measures to exterminate pigs because they were competitors for human resources (Giovas 2006).

Coral island societies relied heavily on tree crops (Figure 6), such as breadfruit, pandanus, and coconut, not only to meet their dietary needs but also to supply raw material for a host of other products (Thaman 1990).
Agroforestry is a distinguishing characteristic of the earliest agriculture in the Pacific islands and is still a prominent component of contemporary atoll landscapes, even in urbanized settings in houseyard and urban gardens. In addition, food preservation technology no doubt reached its zenith on the atolls, as people developed ways to process certain foods that could last through periods of scarcity and for use as sea rations. Fermented breadfruit, dried pandanus paste, and dried arrowroot starch could sometimes be stored for years (Merlin et al. 1997).

There has been one attempt at analyzing core samples from Teraina's peat bogs, which indicated no major vegetation change in the last millennium (Wester et al. 1992). Of the remaining Line and Phoenix islands that appeared to have once supported relatively dense human settlements before abandonment, the question remains as to whether people had successfully introduced cultivars and animal domesticates or subsisted mainly by exploiting wild resources (Anderson et al. 2000, Di Piazza and Pearthree 2001a).

The abandonment of these low coral islands may relate to increased climatic instability during the mid-second millennium A.D., interrupting long-distance exchanges and leading to declines in food resources, both terrestrial and marine, caused by falling sea level (Nunn 2000, 2007:195, Anderson 2002, Nunn et al. 2007; see Drugmore et al. [2007] for an assessment from the North Atlantic). Such atolls are vulnerable to drought and increases in sea-surface temperature (Barnett and Adger 2003). Of course, with more recent human-induced disturbance, ecosystem resilience is reduced. For example, rising concentrations of $\mathrm{CO}_{2}$ in the oceans may retard the ability of reefs to grow in step with sea-level rise.

It is interesting to note that settlement spans the period after about A.D. 1000 until A.D. 1600 at a time when colonists expanded into the marginal East and South Polynesian islands (Anderson et al. 2000, Anderson 2005). Long-distance voyaging may have been facilitated by environmental conditions prevailing at the time, the Medieval Warm Period, bracketed between A.D. 750 


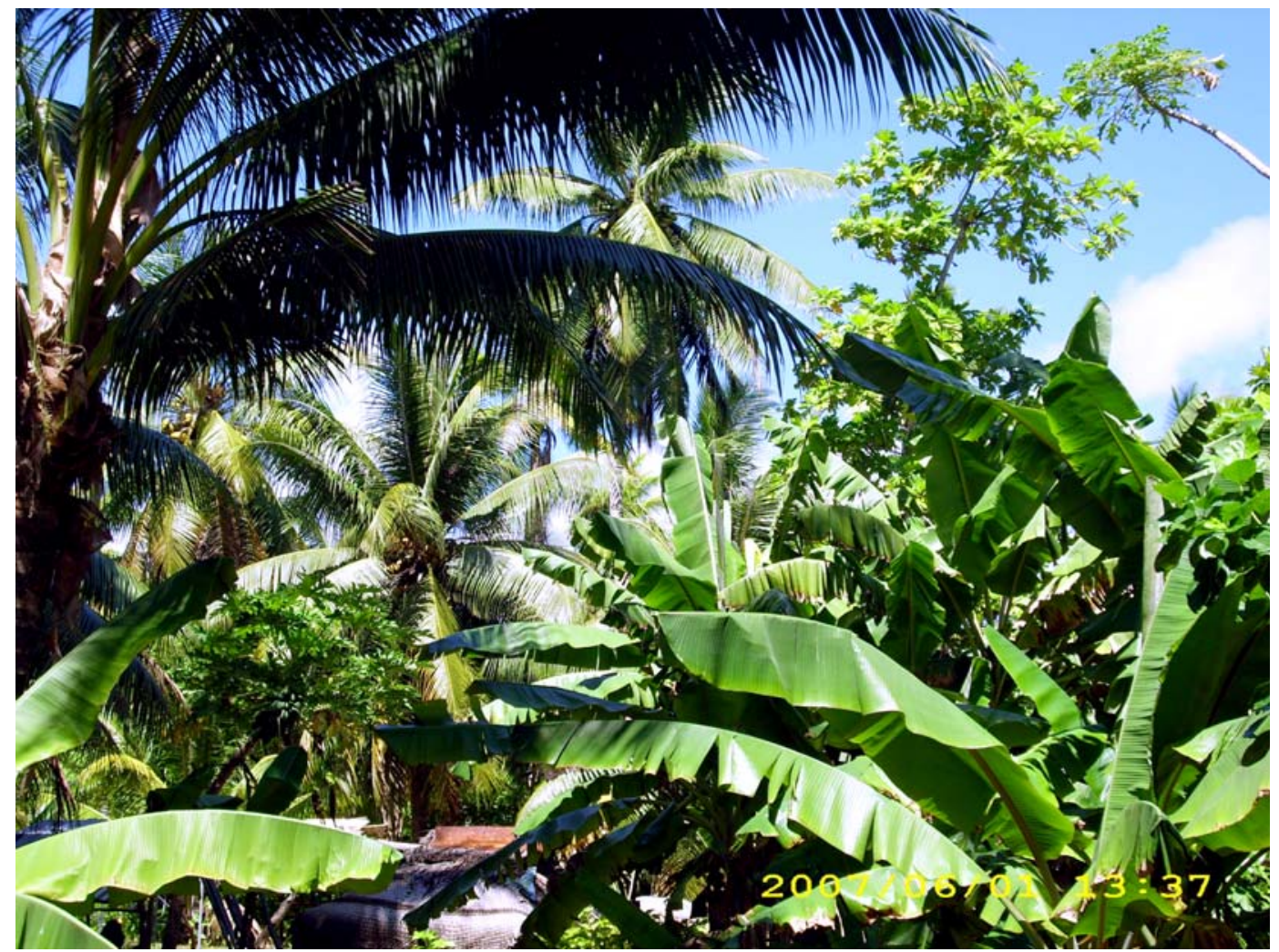

Figure 6. Atoll agroforestry landscape, Abaiang Atoll.

and 1250 (Nunn 2007:59). These conclusions, however, are being challenged by climatic data from the central Pacific (Allen 2006), which highlight the potential influence of climate variability, at a variety of scales, on Pacific peoples and the biota and landscapes with which they interacted.

With the exception of seismic events noted earlier, Kiribati has not been affected by the tectonic processes characteristic of islands found along plate boundaries or close to intraplate hotspots. However, low coral islands are very much affected by seawater erosion and deposition (Figure 7). Thus, atoll geomorphology is very dynamic (Blumenstock 1961, Bayliss-Smith 1988). Islets forming part of a larger atoll have been known to disappear under the waves following a natural catastrophe (cyclone, tsunami) or as a result of more-gradual processes. The obliteration of an isolated table reef or an entire atoll is more unusual. The United States Exploring Expedition (Hale 1846:91) recorded an indigenous account from Makin of a vanished island 'lying about two days' sail (for their canoes) to the northeast" and named Tarawa ni Makin, also known as Karawanimakin. Nunn (2009) analyzed oral traditions of recently vanished islands in Kiribati. Although it is unclear when some of these islands disappeared, other islets, such as Bikeman (Figure 8) in Tarawa Lagoon, have a more detailed history, beginning with changes induced by the construction of causeways in the 1960s, which altered water circulation and the flow of sediments inside the lagoon. Tebua Islet, lying between Tarawa and Abaiang, appeared to have begun eroding away in the midtwentieth century, perhaps as a result of sea-level rise (Moore 2002). 


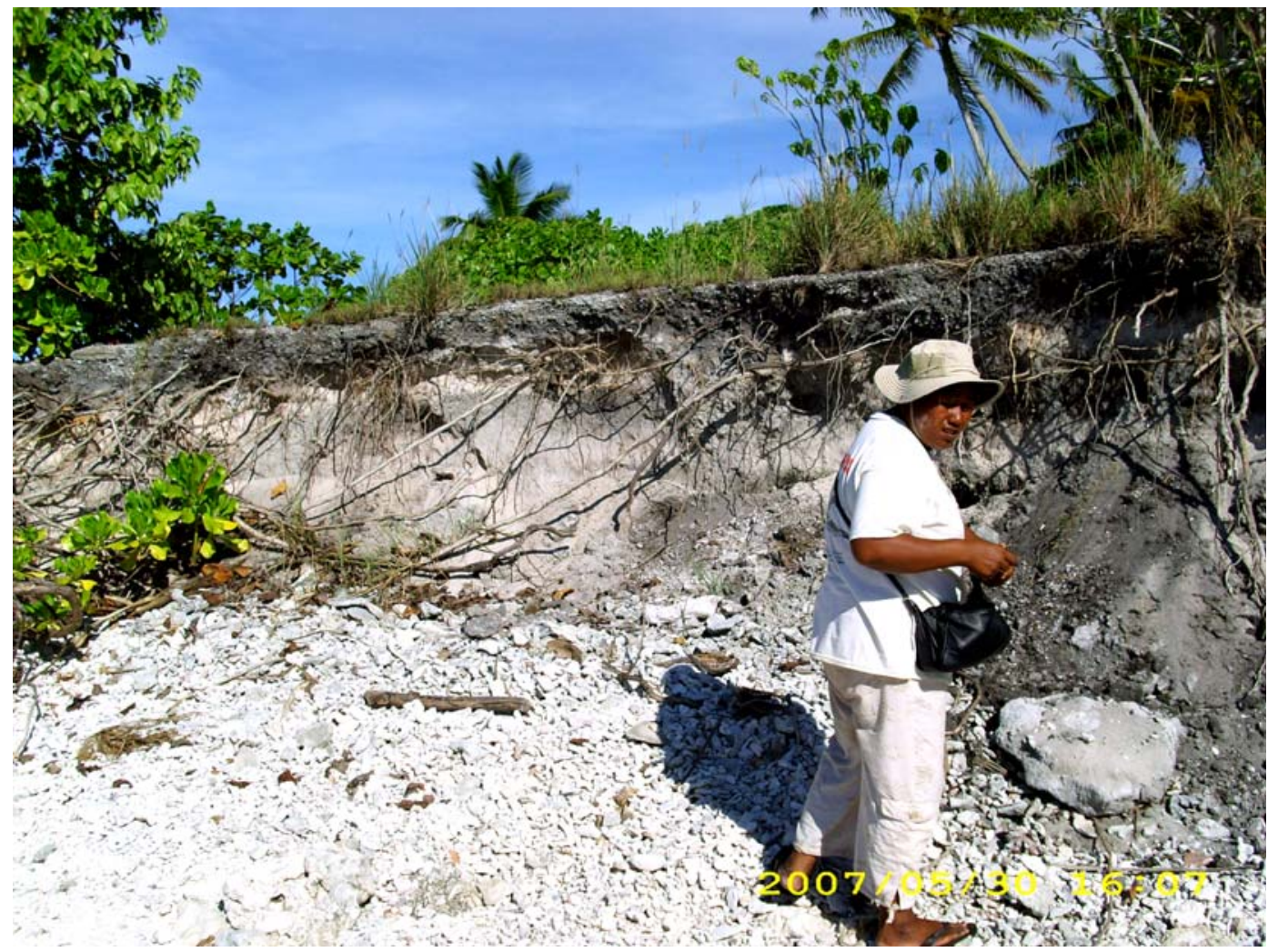

Figure 7. Erosional feature on Manra Islet, Abaiang Atoll.

\section{Anthropogenic Impacts on Faunal Resources}

The very high ratio of reef to land area, typical of most atolls, provided early settlers and their descendants with an abundant source of protein as well as raw material (fish bone, empty shells) for the manufacture of tools and ornaments (Koch 1986). Fishponds and fish traps (Figure 9) made from loosely built walls of coral boulders were used extensively before Western contact (Dieudonne 2002).

What is less clear, however, is the extent of human impact on the marine environment. Elsewhere in Oceania, there is evidence that overfishing by indigenous communities resulted in species-size reduction, particularly of shellfish, that can be distinguished from the effects of natural disturbance (Anderson 1981, Swadling 1986, Spennemann 1987, Allen 2002, 2003). Weisler (2001b) presented evidence for extirpation of the Bullmouth helmet shell (Cypraecassis rufa) from Utrōk Atoll in the Marshalls. However, the presence or absence of marine organisms in a particular habitat appears to be largely dictated by chaotic or unpredictable recruiting events that shape the structure of reef assemblages over a particular period of time (Sale 1980). Such events are also implicated in the distribution of various shellfish species on Tarawa as documented in recent environmental surveys (Paulay 2001, Thomas 2007b). This is not to deny that some species, by virtue of biological, ecological, and behavioral attributes, may display different levels of resilience to human exploitation patterns (Catterall and Poiner 1987). The disappearance of the giant clam, Tridacna gigas, in the Marianas, New Caledonia, and Fiji in the past is a case in point (Munro 1989). Together with other 


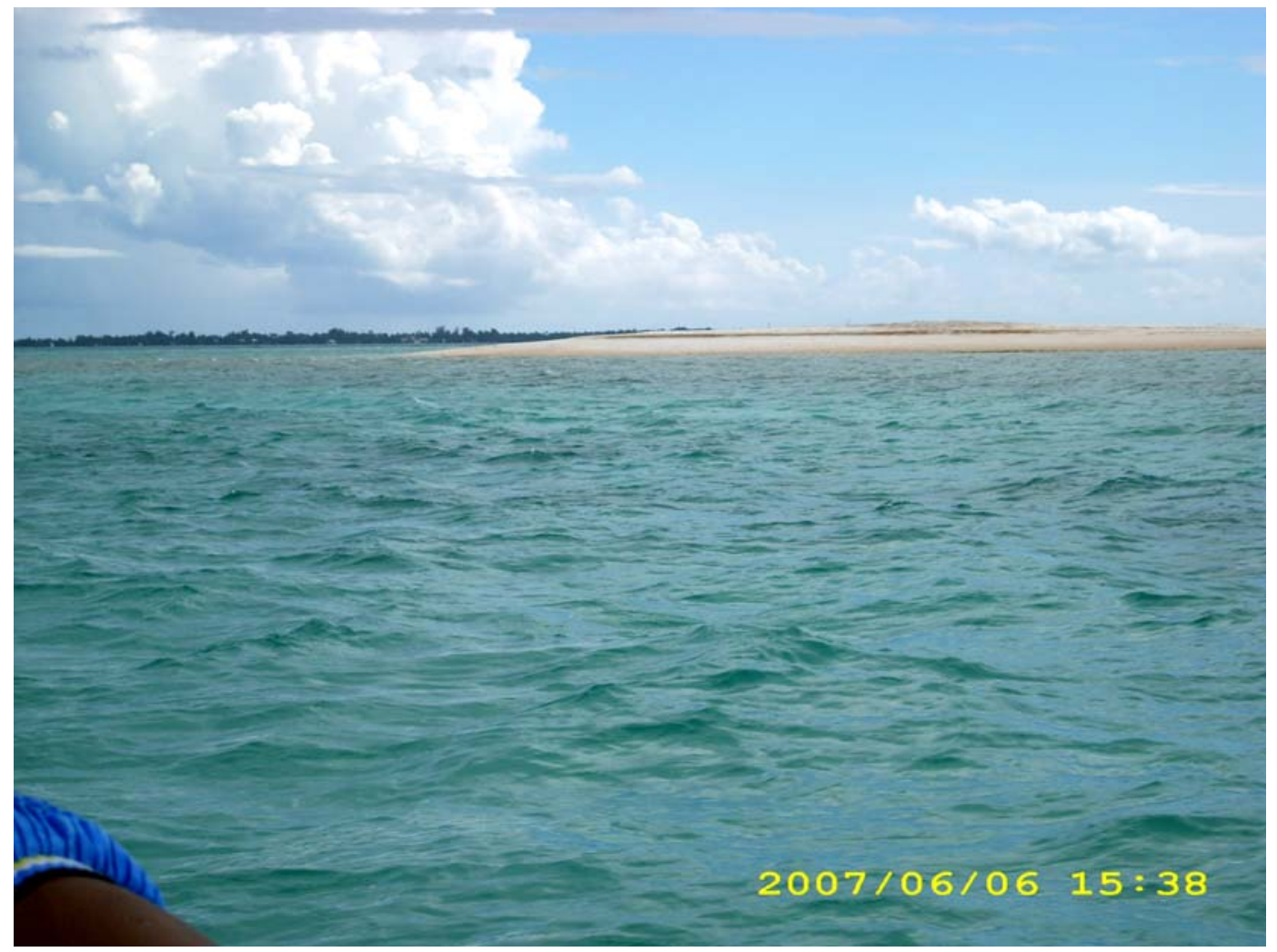

Figure 8. What remains of Bikeman Islet, Tarawa Lagoon.

large members of the Tridacna family, this invertebrate is considered vulnerable to fishing pressure, even when using traditional gathering methods. Yet, as Weisler (2002) noted for his Marshallese data, with relatively low human population on most atolls and the presence of extensive lagoon and ocean-side reefs, marine resources would have generally remained unaffected by human activities. In short, archaeologists lack data on prehistoric resource depression, extirpation, and extinction on low coral islands compared with other insular environments (Steadman 1997). Anderson (2002) further suggested that in the absence of information on prehistoric faunal losses in the Line and Phoenix islands, the demographic histories of these islands could not be explained in terms of anthropogenic environmental change that might have compelled people to abandon their settlements.
In the Marshalls, there is the story of the annan bird that used to live along the shores of the northwestern atolls (Thomas 2004). It is now said to be extinct. It may have been a small ground-dwelling bird, possibly an endemic rail (Spennemann 1991). Rails are known to have become extinct in the past on Wake and Kosrae (Owen 1977), although it appears that extirpation took place during historic times, with the arrival of cats, dogs, rabbits, and European-introduced rats (Steadman 1989, Olson and Ziegler 1995). In addition, some observers have suggested that people living on atolls were more acutely aware of resource limitations than communities on larger continental or volcanic islands and thus realized at an early stage the need to conserve resources (Klee 1985, Zann 1985, Akimichi 1986). 


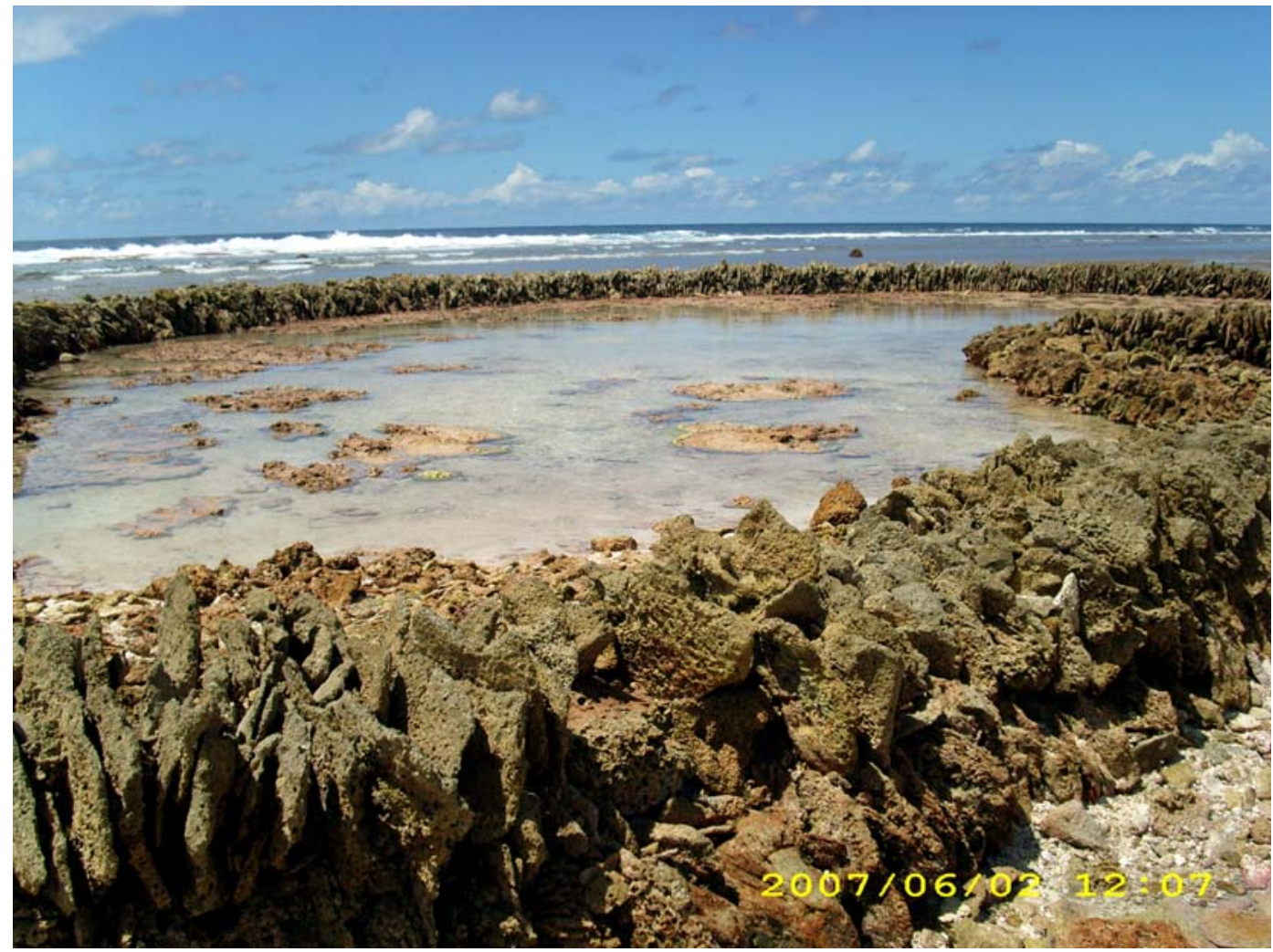

Figure 9. Fish trap, ocean side, Abaiang Atoll.

\section{Environmental Evidence for Human Colonization}

The rapid spread of Lapita from the Bismarcks to the Fiji-Tonga-Samoa area is in marked contrast to the colonization history of the rest of Polynesia and eastern Micronesia. The so-called "long pause" on the order of perhaps 1,000 years or more along the western margins of Polynesia has intrigued archaeologists. Although some radiocarbon dates and environmental proxies, such as charcoal influxes in sediment cores, suggest settlement of the remote eastern Pacific in the first few centuries A.D. or perhaps earlier (e.g., Sutton 1987, Hunt and Holsen 1991, Kirch 1997a), critics point out the unreliability of the dated samples or their precise association with human activities (Spriggs and Anderson 1993, Anderson 1996, Hunt and
Lipo 2006). Nevertheless, on low coral islands where pottery was never manufactured (although it may have been traded, as in the case of outlier atolls of Yap) (Intoh 1992) and where even shell midden deposits can sometimes be ascribed to natural processes rather than human behavior (see Carucci 1992), environmental proxies are often used to identify cultural activities.

Given the dynamic nature of atoll geomorphology mentioned earlier, anthropogenic traces on the landscape can easily be obliterated unless located well inland, such as the soils associated with swamp taro pits. Excavation and dating of paleo surface soils under taro spoil dirt in mounds adjacent to pits by Weisler $(1999 a)$ in the Marshalls yielded evidence of early land clearing. Accordingly, it is expected that the oldest dates for human occupation will be found in association with 
landscape alteration. One of the first tasks that colonists needed to perform was to clear vegetation in preparation for taro pit digging, because corms can take 9 months to several years to mature.

Atoll geomorphology influences both the location of settlements and our ability to identify traces of human activity. Where still in evidence, anthropogenic landscapes provide testimony to human influence on the environment. Although some of these human-induced impacts were certainly destructive, it should be emphasized that life on low coral islands would be considerably more difficult without a fair amount of purposeful modification of the land, as well as portions of the surrounding sea. Indeed, islets that have supported people for an extensive period of time can be characterized as "consummate man-made environments" (Kirch 2000:181).

Research aimed specifically at understanding the relation between the distribution of cultural remains and islet buildup is exemplified by work carried out in the Marshalls (Dye 1987b). On the basis of an ecological model for atoll settlement, the densest (and generally oldest) traces of human occupation are predicted to be on the wider islets, notably in their central portion. This is where the freshwater lens is most developed and thus able to support agricultural production, especially swamp taro (Weisler 1999a, Yamaguchi et al. 2005). Moreover, these areas afforded better protection from salt spray than areas closer to the shoreline. Other environmental parameters for settlement include islet location in relation to the prevailing winds, proximity to canoe passes through the reef, and elevation above sea level in assessing the risk of damage caused by cyclones and high waves (Di Piazza 2005). In addition, given major alteration to parts of the landscape, particularly following major storm events, one can expect changes in islet length and width through time, not to mention complete obliteration (Thomas 2005). However, ecological models of settlement patterns, even for initial settlement, might not adequately explain where people lived in the past. Cultural factors, such as those pertaining to one's status, were shown to determine where high- and low-ranking individual kin groups could establish their residence and organize their activities. As Krämer and Nevermann (1938) reported for the Marshalls, the rank of kin groups, as well as of the different lineages within the same kin group, is indicated by where they live on the atoll. For example, at contact, only the northern atoll of Butaritari and neighboring Makin were ruled by a single paramount chief, and groups displayed clear social distinctions. Most of the other islands were governed by councils of elders and thus were more egalitarian.

Nevertheless, archaeological data from Ujae and Maloelap atolls in the moderately wet central Ratak and Ralik chains of the Marshalls show that in the past there was a tendency for settlements to be aggregated into one main prehistoric village, even on large islets, in association with swamp taro pits (Weisler 1999b, 2001a). The habitation area then expanded from the center toward the lagoon, facilitated by land progradation in that direction. Over time, the other islets, being smaller, were subsequently exploited by people living in the main village for their various resources, including birds, turtles, fish, and shellfish, perhaps the result of a decline in resources near populated areas. It may be that with falling sea level in the mid-second millennium A.D., emerging reef surfaces would have enabled the subsequent development of motus and consequently allowed population dispersal. Later dates for the occupation of smaller motus on the reef support this hypothesis (Nunn 2007:145, 147).

\section{Interisland Exchange Networks and Population Mobility}

The arrival of the first Europeans in the $\mathrm{Pa}$ cific islands in the sixteenth century ushered in a period of major environmental and demographic changes ( $\mathrm{McN}$ ill 2001, Garden 2005, Kirch and Rallu 2007). These processes continue to this day, with many insular habitats facing continued threats from alien species introductions and environmental destruction associated with development (Overton and Scheyvens 1999). Indigenous 
populations now confront the problem of "lifestyle" diseases, notably with declines in nutritional health (Thaman 1988). While urban areas, such as South Tarawa, are experiencing unprecedented population expansion, many outer islands are witnessing population declines. Although the modern-day diaspora of many islanders to Pacific Rim countries and farther afield has not yet impacted Kiribati to a large extent, the I-Kiribati are increasingly mobile, seeking work opportunities overseas and being drawn by the forces of globalization (Borovnik 2006, Connell 2007). Exchange and population mobility are very much part of the contemporary Pacific. But these phenomena have a long pedigree, going back to at least 20,000 years ago in Near Oceania, as evidenced by the distribution of exotic obsidian and animal translocation (Leavesley 2006). Moreover, archaeologists have distanced themselves from a dogmatic approach to studying island societies as "isolates," emphasizing contact between groups instead of perceiving islands and islanders through old Western interpretive lenses where insularity was synonymous with isolation (Lape 2004, D'Arcy 2006, Rainbird 2007, but see Anderson 2004, Cox et al. 2007, Fitzpatrick and Anderson 2008).

From a historical ecology perspective, exchange and population movements are also relevant, in that they provide a basis for understanding some of the adaptive strategies devised by coral islanders in their efforts to establish long-term settlements (Alkire 1978).

Countering earlier views of Pacific island societies as being largely isolated after initial settlement until their rediscovery by Europeans in the early sixteenth century, the occurrence of exotic materials at archaeological sites throughout Oceania has been interpreted as evidence for trade relations between widely dispersed communities. Long-distance exchanges and interisland population movements are thought to have contributed to the success of the Lapita expansion into Remote Oceania (Kirch 1988, Galipaud 2006). Apart from a few exceptions, regional contact persisted right through the historic period and the establishment of colonial governments (D'Arcy 2006). There is little doubt that in- terisland contact remained important for many Oceanic societies and commonly involved the exchange of goods, people, and ideas. But as a result of environmental and social factors, connections likely waxed and waned over time.

Sustained contacts between communities would confer advantages in the event of persistent demographic instability and chronic shortages in food or raw materials as a consequence of environmental perturbation, such as that caused by drought or cyclones (Hunt and Graves 1990). Because of their overall marginality, atolls occupy a prominent position in discussions centered on exchanges. Although this statement is generally valid in comparison with "high" islands, atolls are certainly not uniform in terms of productivity, both terrestrial and marine (Williamson and Sabath 1982). These differences are of course linked to variation in climate and rainfall, but also to intra- and interatoll islet size, as well as the degree of lagoon closure, shape, and depth (Richmond 1993).

Alkire (1978) described various examples of interatoll ties in the form of "clusters" and "complexes." One of the most celebrated cases of extensive networks was the sawai, which hierarchically linked Gagil District on Yap to the atolls of the western Carolines (Oliver 1989:580, Hunter-Anderson and Zan 1996, Descantes 1998), a tribute and exchange network spanning more than 1,000 $\mathrm{km}$. As with other atoll groups, populations in the Marshalls were linked by such intercommunity support networks, which were adaptive in light of the latitudinal variation in rainfall, resulting in differential production of foodstuff between the dry north and the wetter south and the risk of cyclone damage, prompting Marshallese chiefs to secure land holdings scattered over several islets of the same atoll, as well as land rights and rights to resources on other atolls (Spennemann 2006).

Interisland links within the Gilberts in the early postcontact period do not appear to meet the predictions of an exchange network comparable with the model proposed for the early settlement of Remote Oceania, as noted earlier. Neither do they reflect patterns expected for the environmental conditions pre- 
vailing across the archipelago in terms of differential rainfall and agricultural productivity. This is in marked contrast to the situation prevailing in the Marshalls, despite both archipelagoes having a number of environmental and cultural traits in common. The difference in connectivity patterns noted ethnographically between the Marshalls and the Gilberts might relate to alternative evolutionary trajectories that were primarily grounded in social factors, to be examined later. Viewed from a time-depth perspective, it is hypothesized that interisland contacts within the Gilberts once bore greater resemblance to the kind of linkages seen in other parts of Micronesia, including the Marshalls. While the degree of internal variation in terms of rainfall and agricultural productivity, as well as other geographical and environmental factors such as frequency of natural hazards, distance, and island size, appear to be necessary conditions for the development and maintenance of extensive interatoll networks, they are not sufficient conditions. Knudson (1981) downplayed the degree of resource variation in the Gilberts to account for the absence of systematic inter- and intratrading or exchange networks, a view to which I do not subscribe.

As mentioned earlier, societies inhabiting atolls and table reefs could be linked to each other by way of clusters and complexes. The latter are made up of a larger number of coral islands generally under a highly centralized authority that may actually reside in a "high" island setting, such as Yap in the case of the sawai or Tahiti when this polity extended its influence throughout the Tuamotus (Alkire 1978).

In the early postcontact period, and presumably for some time before, the Marshalls formed two main complexes linking the islands of the Ratak (east) and Ralik (west) chains, in addition to several subnetworks (Spennemann 2005). Interisland contacts were probably as frequent as in the central and western Carolines. By contrast, the Gilberts are described as forming a limited number of clusters, namely Makin together with Butaritari at the northern end of the archipelago, separated by only $3 \mathrm{~km}$, and, in precolonial but postcontact period, Abemama and its satellites of Aranuka (about $60 \mathrm{~km}$ distant) and Kuria (approximately $50 \mathrm{~km}$ from Abemama) in the center of the group (Alkire 1978).

What characterized interatoll relations in the early contact period were the prevalence of raiding and consequently the low incidence of trade beyond neighboring islands (Lambert 1975). Because skilled navigators were capable of long-distance sailing, the reluctance to travel far was largely determined by social factors rather than distance or sea conditions (Lewis 1978:165). As Wilkes (1845:82) described, "But, so estranged have the inhabitants of the several islands become from each other, that if a canoe from one of them should visit, or seek, through distress, another island, the persons in it would in all probability be put to death, under the supposition of their being spies, or in order to procure their bones and teeth for the manufacture of ornaments."

The ethnographic present, although useful in our attempts to infer ancient behavior, should always be eyed cautiously when attempting to project known patterns into the more-distant past (see Nunn [2007:162-163] on the conventionalization of warfare, for example). Wilkes (1845:82) again provides an interesting description of patterns of voyaging in the past that differed markedly from those prevailing in his days: "That the islands have been peopled within a period not very remote, is believed by the natives themselves, and they state that only a few generations back the people were much fewer than at present, wars less frequent, and the communication between the islands safe and free."

This might be considered the first clue to the changing patterns of interisland contacts within the Gilberts. Oral traditions, subsequently collected by Grimble (1972) and others, mention that communication was particularly frequent within three subregions of the archipelago: the north, consisting of $\mathrm{Ma}$ kin and Butaritari; the north central atolls of Marakei, Abaiang, Tarawa, and Maiana; and the south central group of Abemama, Kuria, and Aranuka. Voyaging within the southern subgroup of Nonouti, Tabiteuea, Beru, Nikunau, and Onotoa was less common, and 
between the subgroups or to the outlying islands of Tamana and Arorae was a more hazardous journey not to be undertaken lightly. Nevertheless, it was done enough, as witness the many interisland marriages in the local genealogies and the close relationship between the early ruling families of Butaritari, Abaiang, Tarawa, and Abemama (Maude and Doran 1966).

There has been too little archaeological work in the area to provide much supportive evidence for extensive trade networks. A discovery that stands out relates to Conus shell beads on Tamana occurring at two sites that remain undated (Takayama et al. 1989). The investigators concluded that in view of the absence of a lagoon on this table reef, shell resources would be limited and that the ecologically poor island may have traded in the shells and possibly plant food resources from better-endowed environments, possibly from one or more atolls to the north. Ethnohistorical accounts illustrate that shell money strings were a common currency in the northern Gilberts and the Marshalls, and that they were used in exchanges in both eastern and western Micronesia. Nevertheless, it is important to keep in mind that the presence of exotic materials may not necessarily point to human agency. Pumice, a lightweight volcanic rock, which can drift thousands of kilometers before making landfall, was highly valued by both Gilbertese and Marshallese as an abrading material and a source of minerals to fertilize nutrient-poor atoll soils (Sachet 1955, Thomas and Rosenberg 2006). Even obsidian can disperse naturally if attached to pumice or found embedded in the root system of drifting trees (Spennemann and Ambrose 1997).

Using a regional approach to understand island settlement and abandonment in the Line Islands, Di Piazza and Pearthree (2001a) proposed the concept of "mother communities," "satellites," and "isolates" and concluded that resource scarcity and/ or isolation resulting in abandonment are explanations limited to those islands that were relatively inaccessible, small, and/or dry. Some islands appear never to have been inhabited, perhaps because they were too marginal in terms of water availability or because their surrounding reefs prevented effective fishing. Mother communities with high rainfall, such as Tabuaeran, might have supported relatively large resident populations having access to a rich agricultural base by atoll standards. These communities might have periodically exploited nearby satellites (e.g., Kiritimati), which, despite their drier appearance, were located within an overnight voyage of a richer land and offered attractive resources, especially seabirds and turtles. The demise of mother communities remains problematic, but the occurrence of exotic basalt, together with the abundance of timber on certain islands for canoe building, should serve as a reminder that populations were capable of migrating to other archipelagoes. Di Piazza and Pearthree $(2001 b, c)$ identified basalt on Manra (Sydney) in the Phoenix Islands and Tabuaeran in the Line Group derived from the Tataga Matau quarry on Tutuila in American Samoa and from Eiao in the Marquesas, which were transported over distances of 1,075 and $4,425 \mathrm{~km}$, respectively. A single basalt adz bit from the Tataga Matau, and an andesite core of unknown origin, were found on Nikumaroro in 1989; both were surface finds in the colonial village area (T. F. King, pers. comm., 2008). However, these items are not necessarily indicative of trade relations because they could conceivably have been carried by the first colonists.

Despite the migrations, once communication broke down, perhaps as a result of climatic change making long-distance voyaging more hazardous, the sequence of abandonment might have followed a domino effect, particularly when communities faced demographic instability. Deteriorating conditions linked to the A.D. 1300 Event, the prelude to the aforementioned Little Ice Age in the mid-second millennium A.D. would also have jeopardized agricultural resources (Nunn 2007). An interesting parallel exists with the demographic decline or abandonment of several of the Leeward Islands of the Caribbean around A.D. 1300 (Wilson 2007:149), although there is no direct link to environmental change. Rather, it was suggested that escalating tension with popula- 
tions to the south (in the Windward Islands) or with inhabitants in the Greater Antilles resulted in network collapse, which had once played an important role in sustaining groups in the environmentally more marginal islands of the northern Lesser Antilles.

On small relatively impoverished islands, the need to devise strategies for managing population growth may have arisen quickly, so as not to outstrip resources (Firth 1957, Thompson 1970, Bayliss-Smith 1974, Bedford and Macdonald 1982). Warfare, human sacrifice, cannibalism, infanticide, and abortion may contribute to population regulation, but there were also nonviolent means such as moral restraint, ritual celibacy, prolonged lactation, adoption, and several other measures (Alkire 1978, Klee 1980, Spennemann 1990). However, it may be that in some instances underpopulation was a more serious threat to community survival than population pressure (McArthur et al. 1976). In fact, relatively large families, clans, and communities would be necessary to ensure adequate levels of production (Nason 1975).

As in several other low coral island societies, including the Gilberts, populations responded to the vagaries of environmental perturbation in a most successful way: "The atoll populations used flexible social processes for the control of fertility and rates of reproduction; they actively managed recovery from the demographic challenges of contingency events and ensured their continuity as atoll populations occupying enduring settlements" (Green and Green 2007:253).

Reliable estimates of population throughout the Pacific region at the time of European contact are difficult to assess. Estimates for the Gilberts range from 85,000 at the time of the visit by the United States Exploring Expedition in the early 1840s to about 50,000 a decade later (Hale 1846:93, Gulick 1862:410). Much lower figures, between 35,000 and 30,000, have been cited for the early 1860s (Bedford et al. 1980:242). It should be noted that recruiting on foreign ships began in the 1820s (Macdonald 2001:20), thus already exposing islanders to potential diseases at that early stage. However, precontact household and settlement archaeology combined with measures of agricultural production are now offering new insights (Kirch and Rallu 2007), with most case studies deriving from relatively large "high" island contexts. There is growing evidence that many island groups suffered dramatic declines in their population after initial contact with outsiders, although demographers, historians, and archaeologists alike concede that such decline varied in intensity from island to island, and also from place to place in the case of the larger landmasses. Differential population density at the time of contact may have set the stage for the subsequent impact of introduced diseases, with denser settlements suffering the greatest decline because of the higher risk of contagion (Carroll 1975, Cordy 2007).

Although introduced diseases certainly contributed to population decline in the Gilberts, depopulation also followed in the wake of labor migrations to various other Pacific islands, including Hawai' $i$, and beyond. But a more important cause of depopulation in certain islands was continuing intergroup warfare encouraged by political, economic, and religious rivalries once external trade and missionary influence became established (Bedford et al. 1980, Maude and Maude 1981).

\section{Social Evolution}

As Kirch (1997b:18-19) explained in his introduction to a discussion of environmental change and human society in the Pacific islands, historical ecology aims at understanding "the complex and reciprocal connections linking human populations with the myriad other life forms that share their world." $\mathrm{Ha}$ wai' $i$ is one of the best-known case studies for illustrating the interplay between environmental and social parameters, particularly since the Hawaiian Islands had reached a level of political and economic organization unparalleled in Oceania before Western contact (Kirch 1985, 2007). However, the mutually reinforcing processes of population growth, intensification of production, environmental change, and sociopolitical evolution can be documented for several other island groups. 
In opposition, there is little archaeological evidence from low coral islands that would allow us to draw parallels with some of the "high" islands to further our understanding of the "Big Structures and Large Processes" in Oceanic prehistory (Kirch 2000:302-325). That social evolution did take place cannot be doubted, but it appears to be poorly reflected in the archaeological record. The coral island environment certainly imposed limitations on the range of cultural expressions. Because atolls generally lack monumental architecture indicative of social complexity and severely curtailed further agricultural intensification over time, archaeologists need to examine the land- and seascape from a different angle. Historical linguistics and oral traditions may also serve to shed light on some of the social transformations that are presumed to have taken place in the last 2,000 years (Grimble 1972, Maude 1977, Latouche 1984, Tiroba 1989, Teaero and Veramu 1993, Maude and Maude 1994, Teaero 1997).

Coral islands offer limited potential for intensification of food production using traditional methods (Kurika et al. 2007). However, studies of atoll agriculture in the Gilberts show that people have over the centuries selected and improved a variety of tree and root crops, as exemplified by nearly 200 different cultivars of pandanus and over 20 varieties of swamp taro, differing in quality and age at maturity (Luomala 1974, Ali and Asghar 1987, Thaman 1990). In addition, traditional methods of food preservation enabled the accumulation of surplus but were not usually intended to support an elite (Parkinson 1955). Unfortunately, there is little information on yields.

Archaeologists may be able to establish a chronology of taro pits, suggesting that expansion of this kind of food production system could be linked to population increase (Chazine 1983). As noted earlier, with a shift in the subsistence economy after Western contact, few new taro pits were excavated and several were abandoned (Dye 1987a). Likewise, coral-lined fishponds found at a number of places in the Gilberts (Dieudonne 2002) provide evidence for intensification of marine resource production.
The position of the Gilbert Islands at the southeastern end of Micronesia has led to suggestions that it constitutes a "transitional area" or "migrational bridge," in view of the archipelago's proximity to the low coral islands of Tuvalu to the south. The southernmost table reef in the Gilberts, Arorae, is separated from northern Tuvalu by a gap of approximately $340 \mathrm{~km}$. It is not the intention here to reify the Western construct of dividing up Oceania into distinct "culture areas." Rather, the terms "Micronesia" and "Polynesia" are used only as heuristic devices, in line with Kirch and Green's (2001) phylogenetic model. Although the existence of such intermediate cultural expressions has been rejected by some ethnographers (Koch 1986:251255), much oral history, supported by other ethnographic studies, suggests that in the past external links extended to Samoa. Aside from oral traditions that establish a link between the Gilberts and Samoa in the thirteenth century A.D., according to genealogies (Newell 1895, Maude and Maude 1994:135, 251), the most compelling aspect of Samoan influence was a large community meeting house, the maneaba, supported by shaped coral boulders (Figure 10), together with its Samoan fono-type institution. Moreover, the Gilberts' landowning descent units, which were ambilineal in the north and tended to be patrilineal in the south, resembled more closely those of Polynesia than those of other Micronesian societies, which were matrilineal (Alkire 1977:78-80, Oliver 1989:996-997, Rainbird 2004:234235).

Navigational knowledge for a Samoan route supports the likelihood of return voyages, but it has little to say about the frequency of such interaction (Grimble 1972:140, Lewis 1978:123). Other Polynesian influences can be traced to neighboring $\mathrm{Tu}$ valu, and some of the southern Gilberts are said to have supported populations who once spoke Polynesian dialects, but in the course of time they became "Gilbertized" (Oliver 1989:996). Oral traditions tell of Gilbertese who landed on Nui Atoll in Tuvalu, driving away the inhabitants (Sabatier 1977:110, Faaniu et al. 1983:72). The challenge for archae- 


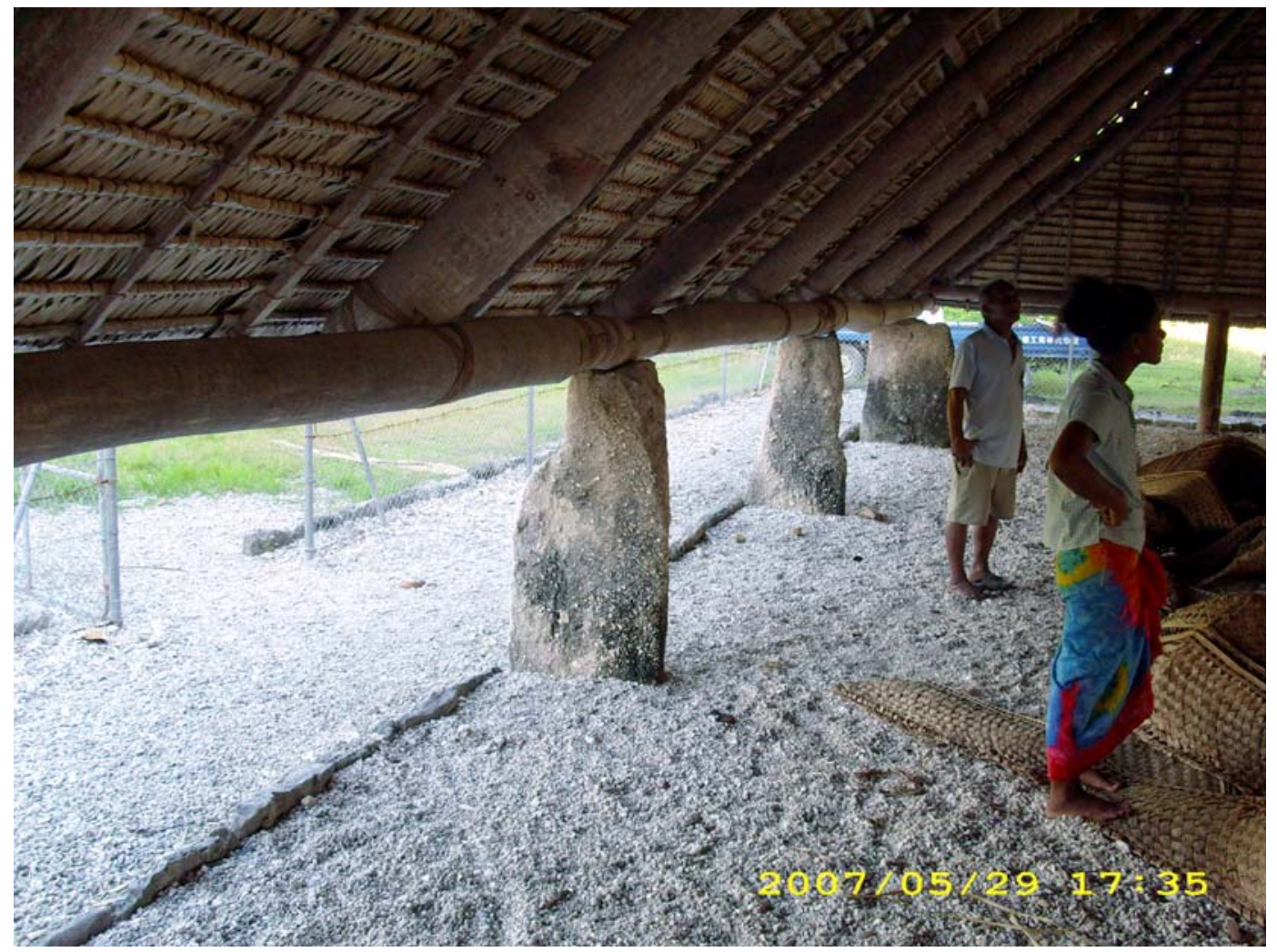

Figure 10. Coral boulder posts of a maneaba, Abaiang Atoll.

ologists will be to identify cultural influences and how these might have impacted the landscape.

In their analysis of Micronesian descent groups and interisland voyaging, Hage and Marck (2002) argued for links between matriliny, the degree of suprafamilial authority, and the regularity of interisland trade (see also Mason 1968, Hage and Harary 1996:159). They believed that relative isolation of the atolls and islands in the eastern Carolines promoted conditions that weakened matriliny. The Gilberts are also cited as having possibly shifted away from an original matrilineal system to a cognatic one, primarily in the northern atolls. One might suggest that a change to a patrilineal system in the southern Gilberts could be attributed to Samoan influence, which is well documented (Oliver 1989:940). The relation between matriliny and voyaging is further explained by
Hage and Marck (2002:166-167): "Unlike patrilocal residence, in which absent husbands must rely on wives from different patrilineages to manage their affairs, in the matrilocal case, absent brothers can rely on lineage sisters to look out for their common corporate interests. The argument implies an absence of internal warfare achieved by forming expeditions around men from different households and villages."

Thus, according to the argument, southern Gilbert Islanders especially have been practicing the kind of short raiding forays described ethnographically partly because of the existing social structure.

\section{CONCLUSIONS}

Although work continues in building up atoll chronologies throughout the Pacific to inter- 
pret both natural and cultural features, there is also a need to address broader patterns and processes similar to those proposed for the "high" islands. Results in that direction have been partially achieved for the atolls and table reefs in the Marshall Islands through a sampling strategy aimed at studying past human adaptation (Weisler 2001c).

Like the Marshalls, the Gilberts are distributed along a north-south axis, displaying major differences in mean annual rainfall but in reverse order in comparison with the Marshalls, with a wetter north and a drier south. Although the risk of cyclones is less than in the Marshalls, the major hazard is drought. As noted earlier, variation also exists in terms of islet and lagoon size and configuration. All these characteristics should provide an ideal setting for examining variation in the type and density of archaeological features, the effects of people on the native biota, and how communities might have developed and changed over time.

Because of their small size, limited and at times fluctuating resources, and relative isolation, low coral islands are of interest for evaluating aspects of past human adaptation to challenging environmental conditions. Yet much remains to be learned regarding their cultural transformation for sustainability before European contact. What stands out is the fact that several communities were able to live sustainably through a combination of relatively small populations, trade and population mobility, and perhaps voluntary conservation measures. An important distinction should be drawn, however, between the effects of conservation and voluntary conservation (conservation by design). But as Smith and Wishnie (2000) argued, sustainability of resource use can still be achieved in the former case; for example, by matching harvest needs, regulating onset or duration of harvests, patch switching to maximize overall returns, and anthropogenic practices that create habitat mosaics (see Sosis 2002, Thomas 2007b).

In a general sense, it can be asserted that islands, and especially atolls, are microcosms of larger, but equally fragile environments (Kirch 2004). From some of the volcanic islands in the Pacific, archaeologists have uncovered evidence for extensive landscape change resulting from vegetation clearing, soil erosion, and species extinction. Debate continues regarding the role of humans versus climatic factors as the leading cause for these changes, but it is reasonable to assume that human impact on the environment exacerbated in some cases the effects of natural disasters, sometimes resulting in major social disruption. More data are needed to evaluate the degree and main causative agent of environmental change in atoll settings.

The implications of this type of research should be clear. The interlinked topics of "sustainability" archaeology, historical ecology, and conservation biology (van der Leeuw and Redman 2002, Lyman and Cannon 2004, Kirch 2005, Hardesty 2007, Kirch and Kahn 2007, Erlandson and Rick 2008) highlight the many challenges faced by communities in the Pacific islands, including atoll populations, as they attempt to cope with changing environments, economies, and social values, which now more than ever pose a threat to sustainable livelihoods. As the noted geographer Harold Brookfield (1980:16) remarked, "one of the more significant trends in modern environmental research is the growing realization of how much can be learned about the present from study of the past." But we need to be cautious in applying lessons from past adaptations in contemporary settings (Rapaport 1990, Spennemann and Alessio 1991, Thomas 1993, Overton 1999, Beardsley 2006). Surely, adjustments will have to be made to assist in developing long-term ecologically secure approaches to survival in the region. For the inhabitants of low coral islands, however, time might be running out and options limited, with the prospect of mass migration linked to climate change and sea-level rise an increasingly likely adaptive scenario. Displaced communities could somehow retain their core cultural values even after several generations, as the Polynesian diaspora tends to suggest. However, several aspects of the tangible cultural heritage, including archaeological and traditional sites, might be irretrievably lost. Consequently, research into the early historical ecology of atolls can ill afford to be postponed. 
ACKNOWLEDGMENTS

I am most grateful to Patrick Nunn, Scott Fitzpatrick, Sharyn Jones, and Tom King for their comments.

\section{Literature Cited}

Abbott, R. R., and J. Garcia, eds. 1995. Management plan for Tarawa Lagoon, Republic of Kiribati. Vol. III: Management plan. BioSystems Analysis, Inc., Santa Cruz, California.

Akimichi, T. 1986. Conservation of the sea: Satawal, Micronesia. Pages 15-33 in A. Anderson, ed. Traditional fishing in the Pacific: Ethnographical and archaeological papers from the 15th Pacific Science Congress. Pac. Anthropol Rec. 37.

Ali, A., and M. Asghar. 1987. The agronomy of Cyrtosperma chamissonis Schott in Kiribati. Alafua Agric. Bull. 12 (3): 81-88.

Alkire, W. H. 1965. Lamotrek Atoll and inter-island socioeconomic ties. Illinois Studies in Anthropology No. 5. University of Illinois, Urbana.

. 1977. An introduction to the peoples and cultures of Micronesia. Cummings, Menlo Park, California.

. 1978. Coral islanders. AHM, Arlington Heights, Illinois.

Allen, M. S. 2002. Resolving long-term change in Polynesian marine fisheries. Asian Perspect. 41:195-212.

2003. Human impact on Pacific nearshore marine ecosystems. Pages 317325 in C. Sand, ed. Pacific archaeology: Assessments and prospects. Département d'Archéologie, Service des Musées et du Patrimoine de Nouvelle Calédonie, Nouméa.

- 2006. New ideas about Late Holocene climate variability in the central $\mathrm{Pa}$ cific. Curr. Anthropol. 47:521-535.

Anderson, A. 1981. A model of prehistoric collecting on the rocky shore. J. Archaeol. Sci. 8:109-120.

. 1996. Adaptive voyaging and subsistence strategies in the early settlement of East Polynesia. Pages 359-373 in T. Akazawa and E. J. Szathmáry, eds. Prehistoric
Mongoloid dispersals. Oxford University Press, Oxford.

. 2002. Faunal collapse, landscape change and settlement history in Remote Oceania. World Archaeol. 33:375-390.

. 2004. Islands of ambivalence. Pages 251-273 in S. M. Fitzpatrick, ed. Voyages of discovery: The archaeology of islands. Praeger, Westport, Connecticut.

2005. Distance looks our way: Remoteness and isolation in early East and South Polynesia. Pages 1-12 in C. Stevenson, J. M. R. Aliaga, F. J. Morin, and N. Barbacci, eds. The Reñaca papers: VI international conference on Easter Island and the Pacific. Easter Island Foundation, Los Osos, California.

Anderson, A., P. Wallin, H. MartinssonWallin, B. Fankhauser, and G. Hope. 2000. Towards a first prehistory of Kiritimati (Christmas) Island, Republic of Kiribati. J. Polynesian Soc. 109:273-293.

Anderson, A., J. Chappell, M. Cagan, and R. Grove. 2006. Prehistoric maritime migration in the Pacific islands: An hypothesis of ENSO forcing. Holocene 16:1-6.

Balée, W., ed. 1998. Advances in historical ecology. Columbia University Press, New York.

Barnett, J., and W. N. Adger. 2003. Climate dangers and atoll countries. Clim. Change 61:321-337.

Bayliss-Smith, T. P. 1974. Constraints on population growth: The case of the Polynesian Outlier Atolls in the precontact period. Hum. Ecol. 2:259-295.

. 1977. Energy use and economic development in Pacific communities. Pages 317-359 in T. P. Bayliss-Smith and R. G. Feachem, eds. Subsistence and survival: Rural ecology in the Pacific. Academic Press, London.

- 1988. The role of hurricanes in the development of reef islands, Ontong Java Atoll, Solomon Islands. Geogr. J. 154:377-391.

Beaglehole, E., and P. Beaglehole. 1938. Ethnology of Pukapuka. B. P. Bishop Mus. Bull. 150.

Beardsley, F. R. 2006. Restoration of traditional knowledge to enhance self- 
sufficiency. Micronesian J. Hum. Social Sci. 5 (1/2): 594-604.

Bedford, R., and B. Macdonald. 1982. The population of Kiribati: A review of some myths about migration and depopulation. Department of Geography, University of Canterbury, Christchurch, New Zealand.

Bedford, R., B. Macdonald, and D. Munro. 1980. Population estimates for Kiribati and Tuvalu 1850-1900: Review and speculation. J. Polynesian Soc. 89:199-246.

Beets, J. 2001. Declines in finfish resources in Tarawa lagoon, Kiribati emphasize the need for increased conservation effort. Atoll Res. Bull. 490.

Bellwood, P. S. 1979. Man's conquest of the Pacific: The prehistory of Southeast Asia and Oceania. Oxford University Press, New York.

Best, S. 1988. Tokelau archaeology: A preliminary report of an initial survey and excavation. Bull. Indo-Pac. Prehist. Assoc. 8:104-118.

Blumenstock, D. I., ed. 1961. A report on typhoon effects upon Jaluit Atoll. Atoll Res. Bull. 75.

Borovnik, M. 2006. Working overseas: Seafarers' remittances and their distribution in Kiribati. Asia-Pac. Viewpoint 47:151161.

Brady, I. A. 1978. Stability and change: Wherewithal for survival on a coral island. Pages 245-281 in C. D. Laughlin Jr. and I. A. Brady, eds. Extinction and survival in human populations. Columbia University Press, New York.

Brookfield, H. C. 1980. Introduction: The conduct and findings of the interdisciplinary Fiji project. Pages $13-28$ in H. C. Brookfield, ed. Population-environment relations in tropical islands: The case of eastern Fiji. UNESCO, Paris.

Buck, P. H. (Te Rangi Hiroa). 1932a. Ethnology of Tongareva. B. P. Bishop Mus. Bull. 92.

1932b. Ethnology of Manihiki and Rakahanga. B. P. Bishop Mus. Bull. 99.

Burgess, S. M. 1987. The climate and weather of western Kiribati. New Zealand Meteorological Service, Wellington.

Carroll, V., ed. 1975. Pacific atoll popula- tions. University Press of Hawai' $\mathrm{i}$, Honolulu.

Carson, M. T. 1998. Cultural affinities of monumental architecture in the Phoenix Islands. J. Polynesian Soc. 107:61-77.

Carucci, J. 1992. Cultural and natural patterning in prehistoric marine foodshell from Palau, Micronesia. Ph.D. diss., Southern Illinois University at Carbondale, Carbondale.

Catala, R. L. A. 1957. Report on the Gilbert Islands: Some aspects of human ecology. Atoll Res. Bull. 59.

Catterall, C. P., and I. R. Poiner. 1987. The potential impact of human gathering on shellfish populations with reference to some NE Australian intertidal flats. Oikos 50:114-122.

Chazine, J.-M. 1983. Rapport de mission à Takapoto (Tuamotu-Polynésie française). Rapport préliminaire. CORDET, Paris.

. 1984. Datations au carbone 14 à Reao. Bull. Soc. Etudes Océan. 228:16541660.

Chikamori, M. 1996. Development of coral reefs and human settlement: Archaeological research in the northern Cook Islands and Rarotonga. Pages 45-52 in I. C. Glover and P. Bellwood, eds. Indo-Pacific prehistory: The Chiang Mai papers. Vol. 2. Indo-Pacific Archaeological Association, Australian National University, Canberra.

Chikamori, M., and S. Yoshida. 1988. An archaeological survey of Pukapuka Atoll, 1985 (preliminary report). Occas. Pap. Dep. Archaeol. Ethnol., Keio Univ. No. 6.

Connell, J. 2007. Island migration. Pages 455-481 in G. Baldacchino, ed. A world of islands: An island studies reader. Institute of Island Studies, University of Prince Edward Island, Charlottetown, PEI.

Cordy, R. 2007. Reconstructing Hawaiian population at European contact: Three regional case studies. Pages 108-128 in P. V. Kirch and J.-L. Rallu, eds. The growth and collapse of Pacific island societies: Archaeological and demographic perspectives. University of Hawai'i Press, Honolulu.

Cox, M. P., A. J. Redd, T. M. Karafet, C. A. Ponder, S. Lansing, H. Sodoyo, and M. F. Hammer. 2007. A Polynesian motif on the 
Y chromosome: Population structure in Remote Oceania. Hum. Biol. 79:525-535.

Crumley, C. L. 1994. Historical ecology: Cultural knowledge and changing landscapes. School of American Research Press, Santa Fe.

D'Arcy, P. 2006. The people of the sea: Environment, identity, and history in Oceania. University of Hawai'i Press, Honolulu.

Davidson, J. M. 1967. Archaeology on coral atolls. Pages 363-375 in G. Highland, R. W. Force, A. Howard, M. Kelly, and Y. H. Sinoto, eds. Polynesian culture history: Essays in honor of Kenneth P. Emory. Bernice P. Bishop Mus. Spec. Publ. 56.

1971. Archaeology of Nukuoro Atoll: A Polynesian Outlier in the eastern Caroline Islands. Bull. Auckl. Inst. Mus. 9.

Descantes, C. 1998. Integrating archaeology and ethnohistory: The development of exchange between Yap and Ulithi, western Caroline Islands (Micronesia). Ph.D. diss., University of Oregon, Eugene.

Dickinson, W. R. 2003. Impact of midHolocene hydro-isostatic highstand in regional sea level on habitability of islands in Pacific Oceania. J. Coastal Res. 19:489502.

Dickinson, W. R., J. Takayama, E. A. Snow, and R. Shutler Jr. 1990. Sand temper of probable Fijian origin in prehistoric potsherds from Tuvalu. Antiquity 64:307312 .

Dieudonne, F., ed. 2002. The Pacific islands and the sea: 350 years of reporting on royal fishponds, coral reefs and ancient walled fish weirs in Oceania. Neptune House, Encinitas, California.

Di Piazza, A. 1999. Te Bakoa site: Two old earth ovens from Nikunau Island (Republic of Kiribati). Archaeol. Oceania 34:4042 .

. 2005. Excavations at Avarua (RAK1): A late archaeological assemblage from a pearl shell workshop on Rakahanga, northern Cook Islands. People Cult. Oceania 20:69-88.

Di Piazza, A., and E. Pearthree. 2001a. An island for gardens, an island for birds and voyaging: A settlement pattern for Kiritimati and Tabuaeran, two "mystery islands" in the northern Lines, Republic of Kiribati. J. Polynesian Soc. 110:149-170. $2001 b$. L'art d'être pirogues de voyage en Océanie insulaire. J. Soc. Océan. 112:61-72.

2001c. Voyaging and basalt exchange in the Phoenix and Line archipelagoes: The viewpoint from three mystery islands. Archaeol. Oceania 36:146-152.

. 2004. Sailing routes of old Polynesia: The prehistoric discovery, settlement and abandonment of the Phoenix Islands. Bishop Museum Press, Honolulu.

Drugmore, A. J., D. M. Borthwick, M. J. Church, A. Dawson, K. J. Edwards, C. Keller, P. Mayewski, T. H. McGovern, K.-A. Mairs, and G. Sveinbjarnardóttir. 2007. The role of climate in settlement and landscape change in the North Atlantic islands: Deviations in high-resolution proxy climatic records. Hum. Ecol. 35:169-178.

Dye, T. 1987a. Archaeological survey and test excavations on Arno Atoll, Marshall Islands. Pages 271-399 in T. Dye, ed. Marshall Islands archaeology. Pac. Anthropol. Rec. 38.

$\longrightarrow$, ed. 1987b. Marshall Islands archaeology. Pacific Anthropol. Rec. 38.

Emory, K. P. 1934a. Tuamotuan stone structures. Bernice P. Bishop Mus. Bull. 118.

1934b. Archaeology of the Pacific equatorial islands. Bernice P. Bishop Mus. Bull. 123.

- 1939. Archaeology of Mangareva and neighboring atolls. Bernice P. Bishop Mus. Bull. 163.

Erlandson, J. M., and T. C. Rick. 2008. Archaeology, marine ecology, and human impacts on marine environments. Pages 1-9 in T. C. Rick and J. M. Erlandson, eds. Human impacts on ancient marine ecosystems: A global perspective. University of California Press, Berkeley.

Faaniu, S., V. Ielemia, T. Isako, T. Isala, L. Kofe, N. Lafita, P. Lafai, K. Laupepa, N. Nia, T. O'Brien, S. Pape, L. Samuela, E. Sapoaga, P. Taafaki, M. Telavi, N. P. Teo, and V. Tinilau. 1983. Tuvalu: A his- 
tory. Institute of Pacific Studies, University of the South Pacific, Suva, Fiji.

Falkland, A. C., and C. D. Woodroffe. 1997. Geology and hydrogeology of Tarawa and Christmas Island, Kiribati. Pages 577-610 in H. L. Vacher and T. M. Quinn, eds. Geology and hydrogeology of carbonate islands. Elsevier, Amsterdam.

Firth, R. 1957. We, the Tikopia. Allen and Unwin, London.

Fitzpatrick, S. M., and A. Anderson. 2008. Islands of isolation: Archaeology and the power of aquatic parameters. J. Int. Coast Archaeol. 3:4-16.

Fitzpatrick, S. M., and T. J. Donaldson. 2007. Anthropogenic impacts to coral reefs in Palau, western Micronesia during the Late Holocene. Coral Reefs 26:915-930.

Fitzpatrick, S. M., and W. F. Keegan. 2007. Human impacts and adaptations in the Caribbean islands: An historical ecology approach. Earth Environ. Sci. Trans. R. Soc. Edinb. 98:29-45.

Galipaud, J.-C. 2001. Le peuplement initial de Pohnpei. J. Soc. Ocean. 112:49-60.

. 2006. The first millennium B.C. in Remote Oceania: An alternative perspective on Lapita. Pages 228-239 in I. Lilley, ed. Archaeology of Oceania: Australia and the Pacific islands. Blackwell, Malden, Massachusetts.

Garden, D. 2005. Australia, New Zealand, and the Pacific islands: An environmental history. ABC-CLIO, Santa Barbara, California.

Geddes, W. H. 1983. Tabiteuea North. Atoll economy: Social change in Kiribati and Tuvalu, No. 2. Australian National University, Canberra.

Geddes, W. H., A. Chambers, B. Sewell, R. Lawrence, and R. Watters. 1982. Islands on the line: Team report. Atoll economy: Social change in Kiribati and Tuvalu, No. 1. Australian National University, Canberra.

Geraghty, P. 1994. Linguistics and central Pacific sailing technology. Pages 59-72 in J. Morrison, P. Geraghty, and L. Crowl, eds. Science of Pacific island peoples: Ocean and coastal studies. Institute of $\mathrm{Pa}$ cific Studies, University of the South Pacific, Suva, Fiji.
Gillie, R. D. 1993. Coastal erosion problems in the Gilbert Islands Group, Republic of Kiribati. South Pac. Comm. Tech. Rep. No. 167.

Giovas, C. 2006. No pig atoll: Island biogeography and the extirpation of a Polynesian domesticate. Asian Perspect. 45:69-95.

Green, V. J., and R. C. Green. 2007. An accent on atolls in approaches to population histories of Remote Oceania. Pages 232256 in P. V. Kirch and J.-L. Rallu, eds. The growth and collapse of Pacific island societies: Archaeological and demographic perspectives. University of Hawai'i Press, Honolulu.

Grimble, A. 1972. Migrations, myth and magic from the Gilbert Islands. Routledge and Kegan Paul, London.

Grossman, E., C. Fletcher, and B. Richmond. 1998. The Holocene sea-level highstand in the equatorial Pacific: Analysis of the insular paleosea-level database. Coral Reefs 17:309-327.

Gulick, L. H. 1862. The Gilbert Islands. Naut. Mag. Nav. Chron. 31:408-414.

Hage, P., and F. Harary. 1996. Island networks: Communication, kinship and classification structures in Oceania. Cambridge University Press, Cambridge.

Hage, P., and J. Marck. 2002. ProtoMicronesian kin terms, descent groups, and interisland voyaging. Oceanic Linguis. 41:159-170.

Hale, H. 1846. United States Exploring Expedition during the years 1838, 1839, 1840,1841 , and 1842 under the command of Charles Wilkes, U.S.N. Vol. 6. Ethnography and philology. C. Sherman, Philadelphia.

Hardesty, D. L. 2007. Perspectives on globalchange archaeology. Am. Anthropol. 109:1-7.

Hoare, R. 1996-1998. World climate, weather and rainfall data. http://worldclimate .com.

Hunt, T. L., and M. W. Graves. 1990. Some methodological issues of exchange in oceanic prehistory. Asian Perspect. 29:107115.

Hunt, T. L., and R. M. Holsen. 1991. 
An early radiocarbon chronology for the Hawaiian Islands: A preliminary analysis. Asian Perspect. 30:147-161.

Hunt, T. L., and C. P. Lipo. 2006. Late colonization of Easter Island. Science (Washington, D.C.) 311:1603-1606.

Hunter-Anderson, R. S., and Y. Zan. 1996. Demystifying the sawei, a traditional interisland exchange system. ISLA: A J. of Micrones. Stud. 4:1-45.

Intoh, M. 1992. Why were pots imported to Ngulu Atoll? J. Polynesian Soc. 101:159168.

- 2008. Ongoing archaeological research on Fais Island, Micronesia. Asian Perspect. 47:121-138.

Irwin, G. 1992. The prehistoric exploration and colonisation of the Pacific. Cambridge University Press, Cambridge.

Jackson, E. O., and S. O. Schlanger. 1976. Regional synthesis, Line Islands Chain, Tuamotu Chain and Manihiki Plateau, central Pacific Ocean. Pages 915-927 in S. O. Schlanger, E. O. Jackson et al. Initial report, deep sea drilling project. U.S. Government Drilling Project, Washington, D.C.

Johannes, R. E., and B. Yeeting. 2001. IKiribati knowledge and management of Tarawa's Lagoon resources. Atoll Res. Bull. 489.

Kennett, D., A. Anderson, and B. Winterhalder. 2006. The ideal free distribution, food production, and the colonization of Oceania. Pages 265-288 in D. Kennett and B. Winterhalder, eds. Behavioral ecology and the transition to agriculture. University of California Press, Berkeley.

Kirch, P. V. 1984. The evolution of the Polynesian chiefdoms. Cambridge University Press, Cambridge.

. 1985. Feathered gods and fishhooks: An introduction to Hawaiian archaeology and prehistory. University of Hawai' $i$ Press, Honolulu.

- 1988. Long-distance exchange and island colonization: The Lapita case. Norw. Archaeol. Rev. 21:103-117.

. 1997a. Changing landscapes and sociopolitical evolution in Mangaia, central Polynesia. Pages 147-165 in P. V. Kirch and T. L. Hunt, eds. Historical ecology in the Pacific islands: Prehistoric environmental and landscape change. Yale University Press, New Haven, Connecticut.

1997b. Introduction: The environmental history of oceanic islands. Pages 1-21 in P. V. Kirch and T. L. Hunt, eds. Historical ecology in the Pacific islands: Prehistoric environmental and landscape change. Yale University Press, New Haven, Connecticut.

- 2000. On the road of the winds: An archaeological history of the Pacific islands before European contact. University of California Press, Berkeley.

2004. Oceanic islands: Microcosms of "global change." Pages 13-27 in C. L. Redman, S. R. James, P. R. Fish, and J. D. Rogers, eds. The archaeology of global change: The impact of humans on their environment. Smithsonian Books, Washington, D.C.

. 2005. Archaeology and global change: The Holocene record. Annu. Rev. Environ. Resour. 30:409-440.

- 2007. Hawaii as a model system for human ecodynamics. Am. Anthropol. 109:8-26.

Kirch, P. V., and R. C. Green. 2001. Hawaiki, ancestral Polynesia: An essay in historical anthropology. Cambridge University Press, Cambridge.

Kirch, P. V., and T. L. Hunt, eds. 1997. Historical ecology in the Pacific islands: Prehistoric environmental and landscape change. Yale University Press, New Haven, Connecticut.

Kirch, P. V., and J. G. Kahn. 2007. Advances in Polynesian prehistory: A review and assessment of the past decade (1993-2004). J. Archaeol. Res. 15:191-238.

Kirch, P. V., and J.-L. Rallu, eds. 2007. The growth and collapse of Pacific island societies: Archaeological and demographic perspectives. University of Hawai'i Press, Honolulu.

Kirch, P. V., and M. I. Weisler. 1994. Archaeology in the Pacific islands: An appraisal of recent research. J. Archaeol. Res. 2:285-328.

Klee, G. A. 1980. Oceania. Pages 245-282 in 
G. A. Klee, ed. World systems of traditional resource management. John Wiley and Sons, New York.

- 1985. Traditional marine resource management in the Pacific. Pages 193202 in J. A. McNelly and D. Pitt, eds. Culture and conservation: The human dimension in environmental planning. Croom Helm, Dover, New Hampshire.

Knudson, K. E. 1981. Adaptational persistence in the Gilbert Islands. Pages 91-99 in R. W. Force and B. Bishop, eds. Persistence and exchange: A symposium. Pacific Science Association, Honolulu.

Koch, G. 1986. The material culture of Kiribati. Institute of Pacific Studies, University of the South Pacific, Suva, Fiji.

Krämer, A., and H. Nevermann. 1938. RalikRatak (Marschall Inseln). In G. Thilenius, ed. Ergebnisse des Südsee-expedition 1908-1910. II ethnographie, B.: Mikronesien. Friedrichsen and de Gruyter, Hamburg.

Kühlman, D. H. H. 1982. Darwin's coral reef research: A review and tribute. Mar. Ecol. 3:193-212.

Kurika, L. M., J. E. Moxon, and M. Lolo. 2007. Agricultural research and development on small islands and atolls: The $\mathrm{Pa}-$ pua New Guinea experience. Pac. Econ. Bull. 22 (3): 126-136.

Lambert, B. 1975. Makin and the outside world. Pages 212-285 in V. Carroll, ed. Pacific atoll populations. University Press of Hawai'i, Honolulu.

Lampert, R. J. 1968. An archaeological investigation on Ocean Island, central Pacific. Archaeol. Phys. Anthropol. Oceania 3:1-18.

Lape, P. V. 2004. The isolation metaphor in island archaeology. Pages 223-232 in S. M. Fitzpatrick, ed. Voyages of discovery: The archaeology of islands. Praeger, Westport, Connecticut.

Latouche, J. P. 1984. Mythistoire Tungaru: Cosmologies et génealogies aux Îles Gilbert. Société d'Études Linguistiques et Anthropologiques de France, Paris.

Lawrence, R. 1983. Tamana. Atoll economy: Social change in Kiribati and Tuvalu, No. 4. Australian National University, Canberra.
Lay, T., and E. Okal. 1983. The Gilbert Islands (Republic of Kiribati) earthquake swarm of 1981-1983. Phys. Earth Planet. Inter. 33:284-303.

Leach, H. M. 1999. Intensification in the $\mathrm{Pa}-$ cific: A critique of the archaeological criteria and their application. Curr. Anthropol. 40:311-339.

Leavesley, M. 2006. Late Pleistocene complexities in the Bismarck Archipelago. Pages 189-204 in I. Lilley, ed. Archaeology of Oceania: Australia and the Pacific islands. Blackwell, Malden, Massachusetts.

Lewis, D. 1978. The voyaging stars: Secrets of the Pacific island navigators. Collins, Sydney.

Liew, J. 1990. Sustainable development and environmental management of atolls. Pages 77-86 in W. Beller, P. d'Ayala, and P. Hein, eds. Sustainable development and environmental management of small islands. UNESCO and Parthenon Publishing Group, Paris, and Park Ridge, New Jersey.

Lundsgaarde, H. P. 1966. Cultural adaptation in the southern Gilbert Islands. Department of Anthropology, University of Oregon, Eugene.

Luomala, K. 1974. The Cyrtosperma systemic pattern: Aspects of production in the Gilbert Islands. J. Polynesian Soc. 83:14-34.

Lyman, R. L., and K. P. Cannon, eds. 2004. Zooarchaeology and conservation biology. University of Utah Press, Salt Lake City.

Lynch, J., M. Ross, and T. Crowley. 2002. The oceanic languages. Curzon, Richmond, Surrey.

Macdonald, B. 2001. Cinderellas of the empire: Towards a history of Kiribati and Tuvalu. Institute of Pacific Studies, University of the South Pacific, Suva, Fiji.

Macgregor, G. n.d. Stone structures of the Phoenix Islands. Ms. on file, Bernice P. Bishop Museum Library, Honolulu.

Marck, J. C. 1986. Micronesian dialects and the overnight voyage. J. Polynesian Soc. 95:253-258.

Marshall, J. F., and G. Jacobson. 1985. Holocene growth of a mid-Pacific atoll: Tarawa, Kiribati. Coral Reefs 4:11-17.

Martinson, D. G., N. G. Pisias, J. D. Hayes, 
J. Imbrie, T. C. Moore Jr., and N. J. Schackleton. 1987. Age dating and orbital theory of the Ice Ages: Development of a high-resolution 0 to 300,000-year chronostratigraphy. Quat. Res. 27:1-29.

Mason, L. 1968. Suprafamilial authority and economic process in Micronesian atolls. Pages 299-329 in A. P. Vayda, ed. Peoples and cultures of the Pacific. Natural History Press, Garden City, New York.

Maude, H. C., and H. E. Maude. 1981. Tioba and the Tabiteuean wars. J. Polynesian Soc. 90:307-336.

- eds. 1994. An anthology of Gilbertese oral tradition. Institute of Pacific Studies, University of the South Pacific, Suva, Fiji.

Maude, H. E. 1977. The evolution of the Gilbertese boti. Institute of Pacific Studies, University of the South Pacific, Suva, Fiji.

Maude, H. E., and E. Doran. 1966. The precedence of Tarawa Atoll. Ann. Assoc. Am. Geogr. 56:269-289.

McArthur, N., I. W. Saunders, and R. L. Tweedie. 1976. Small population isolates: A micro-simulation study. J. Polynesian Soc. 85:307-326.

McNeill, J. R., ed. 2001. Environmental history in the Pacific world. Ashgate, Aldershot.

McQuarrie, P. 2000. Conflict in Kiribati: A history of the Second World War. Macmillan Brown Centre for Pacific Studies, Christchurch, New Zealand.

Menard, H. W. 1986. Islands. Scientific American Library, New York.

Merlin, M., A. Capelle, T. Keene, J. Juvik, and J. Maragos. 1997. Keinikkan im meļan aelōn kein: Plants and environments of the Marshall Islands. East-West Center, Honolulu.

Montaggioni, L. F., and P. A. Pirazzoli. 1984. The significance of exposed coral conglomerates from French Polynesia (Pacific Ocean) as indicators of recent relative sealevel changes. Coral Reefs 3:29-42.

Moore, C. A. 2002. Awash in a rising sea. Int. Wildl. (Jan./Feb.): 1-5.

Munro, J. L. 1989. Fisheries for giant clams (Tridacnidae: Bivalvia) and prospects for stock enhancement. Pages 541-558 in
J. F. Caddy, ed. Marine invertebrate fisheries: Their assessment and management. John Wiley and Sons, New York.

Nason, J. D. 1975. The strength of the land: Community perception of population on Etal Atoll. Pages 117-159 in V. Carroll, ed. Pacific atoll populations. University Press of Hawai'i, Honolulu.

Newell, J. E. 1895. The legend of the coming of Nareau from Samoa to Tarawa, and his return to Samoa. J. Polynesian Soc. 4:231235.

Nunn, P. D. 1998. Pacific island landscapes. Institute of Pacific Studies, University of the South Pacific, Suva, Fiji. 1999. Geomorphology. Pages 43-55 in M. Rapaport, ed. The Pacific islands: Environment and society. Bess Press, Honolulu.

2000. Environmental catastrophe in the Pacific islands around A.D. 1300. Geoarchaeology 15:715-740.

. 2001. Sea-level change in the Pacific. Pages 1-23 in J. Noye and M. Grzechnik, eds. Sea-level changes and their effects. World Scientific Publishing, Singapore. . 2007. Climate, environment and society in the Pacific during the last millennium. Elsevier, Amsterdam.

- 2009. Vanished islands and hidden continents of the Pacific. University of Hawai'i Press, Honolulu.

Nunn, P. D., R. Hunter-Anderson, M. T. Carson, F. Thomas, S. Ulm, and M. J. Rowland. 2007. Times of plenty, times of less: Last-millennium societal disruption in the Pacific Basin. Hum. Ecol. 35:385-401.

Oliver, D. L. 1989. Oceania: The native cultures of Australia and the Pacific islands. University of Hawai'i Press, Honolulu.

Olson, S. L., and A. C. Ziegler. 1995. Remains of land birds from Lisiansky Island, with observations of the terrestrial avifauna of the Northwestern Hawaiian Islands. Pac. Sci. 49:111-125.

Overton, J. 1999. A future in the past? Seeking sustainable agriculture. Pages 227-240 in J. Overton and R. Scheyvens, eds. Strategies for sustainable development: Experiences from the Pacific. Zed Books, London. 
Overton, J., and R. Scheyvens, eds. 1999. Strategies for sustainable development: Experiences from the Pacific. Zed Books, London.

Owen, R. P. 1977. A checklist of birds of Micronesia. Micronesica 13:65-81.

Parkinson, S. 1955. Food conditions in the Gilbert Islands. Trans. Proc. Fiji Soc. 6:61-73.

Paulay, G. 2001. Benthic ecology and biota of Tarawa Lagoon: Influence of equatorial upwelling, circulation, and human harvest. Atoll Res. Bull. 487.

Pawley, A., and M. Ross. 1993. Austronesian historical linguistics and culture history. Annu. Rev. Anthropol. 22:425-459.

Pearthree, E., and A. Di Piazza. 2003. An "Archaic East Polynesian assemblage" from the Phoenix and Line archipelagos. Pages 327-336 in C. Sand, ed. Pacific archaeology: Assessments and prospects. Département d'Archéologie, Service des Musées et du Patrimoine de Nouvelle Calédonie, Nouméa.

Perry, R., and M. Garnett. 1998. Ana otabwanin Kiritimati (The environment of Christmas Island). Ministry of the Line and Phoenix islands, Wildlife Conservation Unit, and BirdLife International, Tarawa and Cambridge.

Pirazzoli, P. A., and L. F. Montaggioni. 1986. Late Holocene sea-level changes in the northwest Tuamotu Islands, French Polynesia. Quat. Res. 25:350-368.

Rainbird, P. 2004. The archaeology of Micronesia. Cambridge University Press, Cambridge.

- 2007. The archaeology of islands. Cambridge University Press, Cambridge.

Rapaport, M. 1990. Population pressure on coral atolls: Trends and approaching limits. Atoll Res. Bull. 340.

Richmond, B. 1993. Reconnaissance geology of the Gilbert Group, western Kiribati. South Pac. Comm. Tech. Rep. No. 77.

Riley, T. J. 1987. Archaeological survey and testing, Majuro Atoll, Marshall Islands. Pages 169-270 in T. Dye, ed. Marshall Islands archaeology. Pac. Anthropol. Rec. 38.

Sabatier, E. 1977. Astride the equator: An ac- count of the Gilbert Islands. Oxford University Press, Melbourne.

Sachet, M.-H. 1955. Pumice and other extraneous volcanic materials on coral atolls. Atoll Res. Bull. 37.

Sale, P. F. 1980. Assemblages of fish on patch reefs: Predictable or unpredictable? Environ. Biol. Fishes 5:243-249.

Schofield, J. C. 1977. Late Holocene sea level, Gilbert and Ellice Islands, west central Pacific. N. Z. J. Geol. Geophys. 20:503-529.

Scoones, I. 1999. New ecology and the social sciences: What prospects for a fruitful engagement? Annu. Rev. Anthropol. 28:479507.

Sewell, B. 1983. Butaritari. Atoll economy: Social change in Kiribati and Tuvalu, No. 3. Australian National University, Canberra.

Shun, K., and J. S. Athens. 1990. Archaeological investigations on Kwajalein Atoll, Marshall Islands, Micronesia. Micronesica Suppl. 2:231-240.

Sigrah, R. K., and S. M. King. 2001. Te rii ni Banaba. Institute of Pacific Studies, University of the South Pacific, Suva, Fiji.

Sinoto, A. 1973. Fanning Island: Preliminary archaeological investigations of sites near the cable station. Pages 283-299 in K. E. Chave and E. A. Kay, eds. Fanning Island expedition: July and August 1972. Hawaii Inst. Geophys. Bull. 73-13.

Sinoto, Y. H., ed. 1984. Caroline Islands archaeology: Investigations on Fefan, Faraulep, Woleai, and Lamotrek. Pac. Anthropol. Rec. 35.

Smith, E. A., and M. Wishnie. 2000. Conservation and subsistence in small-scale societies. Annu. Rev. Anthropol. 29:493-524.

Sosis, R. 2002. Patch choice decisions among Ifaluk fishers. Am. Anthropol. 104:583598.

Spennemann, D. H. R. 1987. Availability of shellfish resources on prehistoric Tongatapu, Tonga: Effects of human predation and changing environment. Archaeol. Oceania 22:81-96.

. 1990. Population control measures in traditional Marshallese culture: A review of 19th century European observations. Archaeology Unit, Alele Museum, Majuro. 
1991. A preliminary checklist of birds and reptiles in the Marshall Islands. Independent Nationwide Radiological Survey Background Study No. 37, Majuro. . 2005. Traditional and nineteenth century communication patterns in the Marshall Islands. Micrones. J. Humanit. Social Sci. 4 (1): 25-52.

- 2006. Freshwater lens, settlement patterns, resource use and connectivity in the Marshall Islands. Transform. Cult. eJournal 1 (2): 44-63.

Spennemann, D. H. R., and D. F. Alessio. 1991. One step back, two steps ahead: The past as a key to sustainable development on coral atolls. HPO Report No. 1991/9, Republic of the Marshall Islands Historic Preservation Office, Majuro.

Spennemann, D. H. R., and W. Ambrose. 1997. Floating obsidian and its implications for the interpretation of Pacific prehistory. Antiquity 71:188-193.

Spriggs, M., and A. Anderson. 1993. Late colonization of East Polynesia. Antiquity 67:200-217.

Steadman, D. W. 1989. Extinctions of birds in eastern Polynesia: A review of the record, and comparisons with other Pacific island groups. J. Archaeol. Sci. 16:177205.

. 1997. Extinctions of Polynesian birds: Reciprocal impacts of birds and people. Pages 51-79 in P. V. Kirch and T. L. Hunt, eds. Historical ecology in the Pacific islands: Prehistoric environmental and landscape change. Yale University Press, New Haven, Connecticut.

Streck, C. F., Jr. 1990. Prehistoric settlement in eastern Micronesia: Archaeology on Bikini Atoll, Republic of the Marshall Islands. Micronesica Suppl. 2:247-260.

Sturman, A. P., and H. A. McGowan. 1999. Climate. Pages 3-18 in M. Rapaport, ed. The Pacific islands: Environment and society. Bess Press, Honolulu.

Sutton, D. G. 1987. A paradigmatic shift in Polynesian prehistory: Implications for New Zealand. N. Z. J. Archaeol. 28:144148.

Swadling, P. 1986. Lapita shellfishing: Evidence from sites in the Reef/Santa Cruz
Group, southeast Solomons. Pages 137148 in A. Anderson, ed. Traditional fishing in the Pacific: Ethnographical and archaeological papers from the 15 th $\mathrm{Pa}$ cific Science Congress. Pac. Anthropol. Rec. 37.

Takayama, J. 1988. A pandanus fruit scraper from Makin Island, Kiribati, central Pacific. Bull. Indo-Pac. Prehist. Assoc. $8: 162-166$.

Takayama, J., and H. Takasugi. 1987. The significance of lure shanks excavated in the Utiroa Site of Makin Island in the Gilberts. Senri Ethnol. Stud. 21:29-41.

1988. Archaeology on Makin, Kiribati, central Pacific. Submitted to Ministry of Home Affairs and Decentralisation, Tarawa. Copies available from Department of Ethnology, Tezukayama University, Nara-shi, Japan.

Takayama, J., H. Takasugi, and K. Kaiyama. 1989. The 1988 archaeological expedition to Kiribati: A preliminary report of $\mathrm{Ta}-$ mana. Tezukayama Univ Rev. 63:1-14. 1990. Test excavation of the Nukantekainga Site on Tarawa, Kiribati, central Pacific. Pages 1-19 in I. Ushijima, ed. Archaeological research on the atoll cultures of Micronesia, 1988. Committee for Micronesian Research 1988, University of Tsukuba, Tsukuba-shi, Japan.

Teaero, T., ed. 1997. Te borau ni Kiribati. Institute of Pacific Studies, University of the South Pacific, Suva, Fiji.

Teaero, T., and M. T. Veramu, eds. 1993. Rokonnanti: Conqueror of lands and other tales from Kiribati. Asian-South Pacific Bureau of Adult Education, Suva, Fiji.

Tebano, T., and G. Paulay. 2001. Variable recruitment and changing environments create a fluctuating resource: The biology of Anadara uropigimelana (Bivalvia: Arcidae) on Tarawa Atoll. Atoll Res. Bull. 488.

Thaman, R. R. 1988. Health and nutrition in the Pacific islands: Development or underdevelopment? GeoJournal 16:211-227. - 1990. Kiribati agroforestry: Trees, people, and the atoll environment. Atoll Res. Bull. 333.

. 1992. Vegetation of Nauru and the Gilbert Islands: Case studies of poverty, 
degradation, disturbance, and displacement. Pac. Sci. 46:128-158.

Thomas, F. R. 1993. Successes and failures on atolls: A review of prehistoric adaptation and contemporary lessons. Pages 423-430 in E. W. Jamieson, S. Abonyi, and N. A. Mirau, eds. Culture and environment: A fragile coexistence. Archaeological Association, University of Calgary, Calgary, Alberta, Canada.

. 1999. The precontact period. Pages 121-133 in M. Rapaport, ed. The Pacific islands: Environment and society. Bess Press, Honolulu.

2001a. Mollusk habitats and fisheries in Kiribati: An assessment from the Gilbert Islands. Pac. Sci. 55:77-97.

. 2001b. Remodeling marine tenure on the atolls: A case study from western Kiribati, Micronesia. Hum. Ecol. 29:399-423.

. 2002a. An evaluation of central-place foraging among mollusk gatherers in western Kiribati, Micronesia: Linking behavioral ecology with ethnoarchaeology. World Archaeol. 34:182-208.

$2002 b$. Self-reliance in Kiribati: Contrasting views of agricultural and fisheries production. Geogr. J. 168:163-177.

. 2003a. Fisheries development in Kiribati: Sustainability issues in a "MIRAB" economy. Pac. Stud. 26 (1/2): 1-35.

- 2003b. Kiribati: "Some aspects of human ecology," forty years later. Atoll Res. Bull. 501.

.2003c. Shellfish gathering in Kiribati, Micronesia: Nutritional microbiological, and toxicological aspects. Ecol. Food Nutr. 42:91-127.

. 2003d. "Taming the lagoon": Aquaculture development and the future of customary marine tenure in Kiribati, central Pacific. Geogr. Ann. Ser. B Hum. Geogr. 85 (4): 243-252.

. 2004. Archaeological survey of Wōtto Atoll. HPO Report 2004/01, Republic of the Marshall Islands Historic Preservation Office, Majuro.

- 2005. An inventory of cultural resources on Mili Atoll. HPO Report 2005/ 01, Republic of the Marshall Islands Historic Preservation Office, Majuro. 2007a. The behavioral ecology of shellfish gathering in western Kiribati, Micronesia. 1: Prey choice. Hum. Ecol. 35:179-194.

- 2007b. The behavioral ecology of shellfish gathering in western Kiribati, Micronesia. 2: Patch choice, patch sampling, and risk. Hum. Ecol. 35:515-526.

Thomas, F. R., and M. D. Rosenberg. 2006. Sea-rafted pumice at Mili Atoll, Marshall Islands: $3000 \mathrm{~km}$ from source. Micrones. J. Humanit. Social Sci. 5 (1/2): 450-457.

Thomas, F. R., and T. Teaero. 2009. Learning about the past today to map future routes: Historic preservation and education in Kiribati. In U. Nabobo-Baba, C. F. Koya, and T. Teaero, eds. Continuity and survival: Oceanic perceptions of education for sustainable development. Asia/Pacific Cultural Center, UNESCO, Tokyo (in press).

Thomas, F. R., and K. Tonganibeia. 2007. Pacific island rural development: Challenges and prospects in Kiribati. Pages 38-55 in J. Connell and E. Waddell, eds. Environment, development and change in rural Asia-Pacific: Between local and global. Routledge, London.

Thompson, L. 1970. A self-regulating system of human population control. Trans. N. Y. Acad. Sci. 2 (32): 262-270.

Throssel, B., and J. Specht. 1989. Stone structures on McKean Island, Phoenix Islands, Republic of Kiribati. Aust. Archaeol. 29:17-21.

Tiroba, T. 1989. Traditional stories from the northern Gilberts. Institute of Pacific Studies, University of the South Pacific, Suva, Fiji.

van der Leeuw, S., and C. L. Redman. 2002. Placing archaeology at the center of socionatural studies. Am. Antiq. 67:597-605.

Van Trease, H., ed. 1993. Atoll politics: The Republic of Kiribati. Macmillan Brown Centre for Pacific Studies, University of Canterbury and Institute of Pacific Studies, University of the South Pacific, Christchurch, New Zealand, and Suva, Fiji.

Watters, R., and K. Banibati. 1984. Abemama. Atoll economy: Social change in 
Kiribati and Tuvalu, No. 5. Australian National University, Canberra.

Wester, L., J. O. Juvik, and P. Holthus. 1992. Vegetation history of Washington Island (Teraina), northern Line Islands. Atoll Res. Bull. 358.

Weisler, M. I. 1999a. The antiquity of aroid pit agriculture and significance of buried A horizons on Pacific atolls. Geoarchaeology 14:621-654.

- 1999b. Atolls as settlement landscapes: Ujae, Marshall Islands. Atoll Res. Bull. 460.

- 2000. Burial artifacts from the Marshall Islands: Description, dating and evidence for extra-archipelago contacts. Micronesica 33:111-136.

2001a. Archaeological excavation at site MLMI-3, Kapen Islet, Maloelap Atoll, Marshall Islands. Report prepared for the Historic Preservation Office, Republic of the Marshall Islands. Available from the author.

. 2001b. Life on the edge: Prehistoric settlement and economy on Utrōk Atoll, northern Marshall Islands. Archaeol. Oceania 36:109-133.

. 2001c. Precarious landscapes: Prehistoric settlement of the Marshall Islands. Antiquity 75:31-32.

- 2002. Archaeological survey and test excavations on Ebon Atoll, Republic of the Marshall Islands. Report prepared for the Historic Preservation Office, Republic of the Marshall Islands. Available from the author.

Wiens, H. J. 1962. Atoll environment and ecology. Yale University Press, New Haven, Connecticut.

Wilkes, C. 1845 . The narrative of the United
States Exploring Expedition during the years 1838, 1839, 1840, 1841, and 1842 . Vol. 5. Lea and Blanchard, Philadelphia.

Williamson, I., and M. D. Sabath. 1982. Island population, land area, and climate: A case study of the Marshall Islands. Hum. Ecol. 10:71-84.

Wilson, S. M. 2007. The archaeology of the Caribbean. Cambridge University Press, Cambridge.

Woodroffe, C. D., and R. F. McClean. 1998. Pleistocene morphology and Holocene emergence of Christmas (Kiritimati) Island, Pacific Ocean. Coral Reefs 17:235248.

Woodroffe, C. D., and R. J. Morrison. 2001. Reef-island accretion and soil development on Makin, Kiribati, central Pacific. CATENA 44:245-261.

World Bank. 2000. Impact of climate change on low islands: The Tarawa Atoll, Kiribati. Pages 19-26 in Cities, seas, and storms: Managing change in Pacific island economies. Vol. IV: Adapting to climate change. World Bank, Washington, D.C.

Yamaguchi, T., H. Kayanne, H. Yamano, Y. Najima, M. Chikamori, and H. Yokodi. 2005. Excavation of pit-agriculture landscape on Majuro Atoll, Marshall Islands and its implications. Global Environ. Res. 9 (1): 27-36.

Zann, L. P. 1985. Traditional management and conservation of fisheries in Kiribati and Tuvalu atolls. Pages 53-77 in K. R. Ruddle and R. E. Johannes, eds. The traditional knowledge and management of coastal systems in Asia and the Pacific. UNESCO/Regional Office for Science and Technology for Southeast Asia, Jakarta. 